\title{
Mercuric Chloride induced Oxidative Stress, Genotoxicity, Haematological Changes and Histopathological Alterations in Fish Channa Punctatus (Bloch, 1793).
}

\section{Sunil P. Trivedi}

University of Lucknow Faculty of Science

\section{Shefalee Singh}

University of Lucknow Faculty of Science

Abha Trivedi

M J P Rohilkhand University Faculty of Applied Sciences

Manoj Kumar ( $\sim$ mk2016lu@gmail.com)

University of Lucknow Faculty of Science https://orcid.org/0000-0001-9895-0685

\section{Research Article}

Keywords: Mercury chloride, Genotoxicity, Oxidative stress, Histopathological alterations, Haematological changes

Posted Date: June 28th, 2021

DOl: https://doi.org/10.21203/rs.3.rs-640856/v1

License: (c) (i) This work is licensed under a Creative Commons Attribution 4.0 International License. Read Full License

Version of Record: A version of this preprint was published at Journal of Fish Biology on February 23rd, 2022. See the published version at https://doi.org/10.1111/jfb.15019. 


\section{Abstract}

The current study was strived to investigate the adverse effects of Mercuric chloride $\left(\mathrm{HgCl}_{2}\right)$ overload in the fish Channa punctatus. Two sub-lethal test concentrations of $\mathrm{HgCl}_{2}$ viz., 1/20th and 1/10th of $96 \mathrm{~h}$ $\mathrm{LC}_{50}$ i.e., $0.03 \mathrm{mg} / \mathrm{L}$ and $0.07 \mathrm{mg} / \mathrm{L}$, respectively, were used for exposure. Blood, liver and kidney tissues of the control and exposed specimens were sampled at intervals of 15, 30 and 45 days to assess alterations in oxidative stress, genotoxicity haematological parameters and histopathology. Significant changes in $\mathrm{Hb} \%$, RBC count, WBC count, antioxidant enzyme activity viz., super oxide dismutase (SOD), catalase (CAT), glutathione (GSH) and glutathione reductase (GR) were recorded. Micronuclei (MN) induction, nuclear abnormalities (NA) and histopathological alterations were also observed in the exposed fish. Significant $(p<0.05)$ increase in activities of SOD, CAT, GSH, GR and after $45 \mathrm{~d}$ decrease in the level of GSH and GR suggest an undermined anti-oxidative defence system in the fish exposed to $\mathrm{HgCl}_{2}$. Histological examination of liver and kidney showed serious tissue injury and histological alterations. Significant increase in MN and NA frequencies reveal the DNA damage in erythrocytes of fish and haematological changes show the toxicological potential of $\mathrm{HgCl}_{2}$. The observed genotoxicity, biochemical, haematological and histological changes in the present study provide the most extensive insight of $\mathrm{HgCl}_{2}$ stress in Channa punctatus.

\section{1.introduction}

Heavy metals are tainting the aquatic habitats and very badly affecting the aquatic organisms. Worldwide, heavy metal contamination is turning into the most genuine condition issue to the environment (Pushkar et al., 2019). Various reports have affirmed that heavy metals and other poisonous compounds are majorly responsible for the degradation of health of many rivers in India (Javed, 2015; M. Kumar et al., 2019; Siddiqui \& Pandey, 2019). Mercury sullying in the environment presents genuine medical problem to humans and to flora and fauna in water bodies (Dash \& Das, 2015).

Mercury $(\mathrm{Hg})$ is a highly hazardous pollutant exceedingly bio accumulative and displays a chemical speciation in the environment majorly in three forms elemental, inorganic (iHg) and organic, all of which are toxic (Rice et al., 2014). However, the principal natural and anthropogenic emissions of mercury exist as inorganic form i.e., Mercuric (II) chloride https://www.epa.gov/mercury/basic-information-aboutmercury. Although exceedingly toxic, this odourless, colourless substance is utilized in various kind of applications viz., agriculture, medicine, chemical industries etc.

https://www.britannica.com/science/mercury-chemical-element/Principal-compounds. Mercuric II chloride gets entry into water or soil from the weathering of rocks that contain mercury, release of water containing mercury from factories or water treatment plants and from incineration of municipal waste (for example, in thermometers, electrical switches, fluorescent light bulbs, or batteries that have been thrown away) https://www.atsdr.cdc.gov/PHS/PHS.asp?id=112\&tid=24. Mercury chloride has caused an increase in various types of tumours in mice and rats. The EPA has determined that mercury chloride is a potential human carcinogen. Harmful effects of mercury that can affect the foetus include brain damage, 
intellectual disability, coordination problems, blindness, seizures and speech disorders. Children with mercury poisoning can develop nervous and digestive problems as well as kidney damage (Friis, 2012).

With concern to mercury pollution, aquatic habitats are highly affected zone in which mercury is considered as major threat for aquatic organisms. The target organ for mercury is the nervous system but it can impair any organ (Mercury Contamination of Aquatic Ecosystems, 2018). In fishes it has been documented that mercury affects various organs viz., the brain (Morcillo et al., 2017; Pandey, 2012; Rice et al., 2014) muscles (Kimáková et al., 2018; Łuczyńska et al., 2016) immune systems and immune response (Minoia et al., 2009) and the reproductive system (Crump \& Trudeau, 2009a). It has also been observed that mercury is very dangerous and highly toxic chemical in the environment which can cause structural degeneracy of cells, imbalance in antioxidant system, variations of energy metabolism, disturbance in calcium homeostasis and induction of genotoxicity (Berg et al., 2010; Berntssen et al., 2003; Yadav \& Trivedi, 2009a, 2009b). Any chemical form of mercury has the potential to disrupt proteins, inactivate enzymes and cause critical changes in the physiological activities of any tissue with which it may come in contact in adequate concentration (Crump \& Trudeau, 2009b; Gonzalez et al., 2005; K. V. Sastry and Sharma, 1980; K. V. Sastry \& Rao, 1981; Suhendrayatna et al., 2019; Vasanthi et al., 2019a). The liver and kidney are the primary organs responsible for the regulation of metabolic pathways, maintenance of body equilibrium and detoxification (Awasthi et al., 2018; Kumar et al., 2019; Ratn et al., 2018) therefore, mercury can affect these organs severely and impair their functional role by interfering with key physiological and metabolic processes. Assessment of different biomarkers in blood is an imperative and sensitive index, they play a crucial role in toxicological studies, the obtained experimental data help in clinical correlation (Olayode et al., 2020; Perveen et al., 2019).

The mechanism of $\mathrm{HgCl}_{2}$ toxicity is related with the generation of intracellular reactive oxygen species (ROS), which can initiate cellular damage (Ahmad \& Mahmood, 2019; Livingstone, 2001). Cappello et al., (2016) documented that oxidative stress is a key pathway to initiate mercury toxicity in fish. Evaluation of activities of important antioxidant enzymes, viz., SOD, CAT, GSH and GR clearly reflect the expanse of oxidative stress (Kumari et al., 2014). Unfortunately, relatively little is known about the hematological changes, genotoxicity and histopathological alterations under chronic exposure of $\mathrm{HgCl}_{2}$. To get illustration of above-mentioned parameters under the stress of $\mathrm{HgCl}_{2}$ different markers were studied. $\mathrm{MN}$ assay is one of the commonly used test for the evaluation of DNA damage induced by different aquatic pollutants in fish (Andrianopoulos et al., 2006; Dwivedi et al., 2017; Mahboob et al., 2013; Shukla \& Trivedi, 2019). DNA damage can best be shown by MN induction and, thus, it can be use efficiently to have sight of genotoxicity. Some studies have also mentioned, in addition to MN, the presence of other nuclear abnormalities, such as blebbed, lobed, binucleated, and notched nuclei, indicating that these abnormalities need to be seen similar to MN induction, and, thus, must be considered as potential indicators of genotoxicity (Abara et al., 2016; Anbumani \& Mohankumar, 2011; Ansari et al., 2009; Çavaş \& Ergene-Gözükara, 2005a; Nirchio et al., 2019; Shahjahan et al., 2020). The hematological parameters viz., $\mathrm{RBC}$ count, WBC count and $\mathrm{Hb} \%$ have been used as potential indicator of stress induced by various pollutants in fish (Ates et al., 2008; Bujjamma \& Padmavathi, 2018; Kumar et al., 2011). Heavy metals 
cause histological damage in the fish with an inflammatory defensive reaction (Álvarez-Muñoz et al., 2009; Berntssen et al., 2003; Macirella et al., 2016; Mela et al., 2007). It is peremptory that histological alterations are the markers of pollutants in the complete health of organism in the ecosystem (VelkovaJordanoska \& Kostoski, 2005). The study of histological alterations in organs viz., liver and kidney of fish is precise way to assess the effects of aquatic pollutants in experimental studies.

Many studies have documented different mercury concentrations given through food and aqueous medium using both short and long term exposures; various biological parameters been implemented to detect the impact of this toxic heavy metal on fish liver and kidney viz., quantification of genes expression, proteomic, transcriptome analysis, DNA microarray, biochemical analysis (Bleau et al., 1996; de Jesus et al., 2011; Gonzalez et al., 2005; Mela et al., 2014; Yong Ung et al., 2010) but very little amount of information is present on oxidative stress, genotoxicity, hematological and histopathological alterations (Berntssen et al., 2003; M. Mela et al., 2007; Yadav \& Trivedi, 2009a). Ample of data is available on the toxicity of methyl mercury (MeHg) (Pal et al., 2012; Pandey, 2012; Souza-Araujo et al., 2016; Suhendrayatna et al., 2019; Vasanthi et al., 2019) but the effects of $\mathrm{HgCl}_{2}$ have been considerably neglected despite the fact that $\mathrm{HgCl}_{2}$ primarily gets accumulated in the liver and kidney of fishes (Peressutti et al., 2008; Régine et al., 2006). This study is conducted to fill this gap and investigate different parameters viz., oxidative stress, genotoxicity, histopathological and hematological alterations induced by $\mathrm{HgCl}_{2}$ in liver and kidney of fish Channa punctatus.

\section{Materials And Methods}

\subsection{Test chemical}

$\mathrm{HgCl}_{2}$ manufactured by S.D Fine-chem Ltd., Mumbai, India was purchased from a local dealer. Analytical grade chemical was used in the study.

\section{2. $96 \mathrm{~h}-\mathrm{LC}_{50}$ of $\mathrm{HgCl}_{2}$ for fish, Channa punctatus}

The standard acute toxicity bioassay under OECD guidelines for fish acute bioassays (OECD203, 92/69/EC, method C1) and the standard methods of APHA, (2012) were used to find out $96 \mathrm{~h} \mathrm{LC}_{50}$ of $\mathrm{HgCl}_{2}$ for $C$. punctatus. To ascertain approximate toxic range of the test chemical, ten healthy, equal sized and well acclimatized fish $\left(30 \pm 3.0 \mathrm{~g} ; 14.5 \pm 1.0 \mathrm{~cm}\right.$ ) were exposed to definite concentrations of $\mathrm{HgCl}_{2}$ on a logarithmic scale viz., $0.1,1.0,10,100$ and $1000 \mathrm{mg} / \mathrm{L}$ up to $96 \mathrm{~h}$ in a semi static bio assay system. Fishes were loaded at the rate $4 \mathrm{~g}$ fish per litre of water (Burress, 1975). The toxicity range of $\mathrm{HgCl}_{2}$ on the basis of mortality was found between 0.1 and $1.0 \mathrm{mg} / \mathrm{L}$. After ascertaining approximate toxic range, ten distinct logarithmic concentrations viz., $0,0.2,0.4,0.6,0.8,1.0,1.2,1.4 \mathrm{mg} / \mathrm{L}$ were selected to determine the $\mathrm{LC}_{50}$ value of $\mathrm{HgCl}_{2}$. The percentage fatality of fish was noted up to $96 \mathrm{~h}$ of exposure period. Experiments were repeated three times to check its reproducibility. Probit analysis method (Finney, 1971) was used to determine $96 \mathrm{~h} \mathrm{LC}_{50}$ values of $\mathrm{HgCL}_{2}$. 


\subsection{Experimental setup}

The Channa punctatus has been selected for this study. Healthy specimens $(30 \pm 5.0 \mathrm{~g} ; 15 \pm 1.0 \mathrm{~cm})$ of fish, acquired through fishermen from aquatic habitats of Lucknow (Longitude $26^{\circ} 55^{\prime} \mathrm{N}$, Latitude $80^{\circ} 59^{\prime}$ E), Uttar Pradesh, India. Fish were transported to the laboratory and treatment of $0.05 \% \mathrm{KMnO}_{4}$ solution for 2-5 min was given, to avoid external infections if any (Awasthi et al., 2018). Fish were acclimatized to laboratory conditions for 15 days in $160 \mathrm{~L}$ properly ventilated glass aquaria $\left(100 \times 40 \times 40 \mathrm{~cm}^{3}\right)$ loaded with $100 \mathrm{~L}$ of 15 days aged tap water (APHA, 2012). During acclimatization period commercial aquarium food pellets (Perfect Companion Group Company Limited, Thailand) were given to fish. Fish were kept without feeding one day before the starting of experiment. (OECD, 2019). Total 45 fish were erratically divided into three groups each having 15 fish, group I served as control, group II $-0.03 \mathrm{mg} / \mathrm{L}$ of $\mathrm{HgCl}_{2}$ (96 $\left.\mathrm{h}-\mathrm{LC}_{50} / 20\right)$, group III $-0.07 \mathrm{mg} / \mathrm{L}\left(96 \mathrm{~h}-\mathrm{LC}_{50} / 10\right)$ of $\mathrm{HgCl}_{2}$. Every group was maintained in triplicate in separate aquaria. No fish were found dead across the experiment. Sequentially, aquaria were emptied every day to avoid accumulation of waste and excretory materials (Palermo et al., 2015). After each exposure period $(15,30$ and 45$)$ three fish from each replicate were insentient by using $0.1 \%(\mathrm{v} / \mathrm{w})$ diethyl ether and their blood was draw through a heparinized syringe and stored in EDTA $(1.8 \mathrm{mg} / \mathrm{mL})$ coated vials for the evaluation of MN, NA and haematological parameters. After sacrificing the fish, liver and kidney samples were collected for the estimation of the $\mathrm{HgCl}_{2}$ induced damage, viz., oxidative stress and histopathological alterations.

\subsection{Genotoxicity measurement: Micronucleus test and Nuclear abnormalities.}

Micronuclei frequencies were estimated by following methods of Kumar, 2012; Schmid, 1975 and methodologies practised earlier in our laboratory (Awasthi et al., 2018; Yadav \& Trivedi, 2009a). Nuclear abnormalities were identified according to (Anbumani \& Mohankumar, 2011; Shahjahan et al., 2020).

\subsection{Haematological analysis}

The total erythrocytes and leucocytes counts were done by Neubauer haemocytometer (Shah and Altindag, 2004). Hayem's fluid was used to dilute (1:200) blood (Mishra et al., 1977) for erythrocytes and Turks fluid was used to dilute the blood (1:20) for leucocytes. Diluted blood was loaded on haemocytometer chamber then erythrocytes and leucocytes were counted. Expressed as $10^{3} / \mathrm{mm}^{3}$ (Wintrobe 1967).

Hemoglobin percentage $(\mathrm{Hb} \%)$ was calculated by Sahli method (Godkar and godkar, 2003). $\mathrm{Hb} \%$ was expressed as $\mathrm{g} / \mathrm{dL}$.

\subsection{Histopathology of liver and kidney}

The liver and kidney tissues were cleaned with $0.9 \% \mathrm{NaCl}$ solution to remove impurities. Fixation of tissues was done in Bouin's fluid for $48 \mathrm{~h}$ and after that washing was done twice a day with $70 \%$ ethanol for four to five days to remove extra Bouin's fluid. Tissues were dehydrated in graded series of ethanol, 
cleaned with xylol and later inserted in paraffin wax to get blocks. Blocks were stored overnight in $4^{0} \mathrm{C}$. Microtome (YSI062 Yorco Precision Rotary Microtome, India) was used for sectioning ( $1 \mathrm{~mm}$ ) of tissues. Sections were placed on hot plate for flattering and stained with hematoxylin for one minute and eosin was used to counterstaining for two minutes. After proper processing sections were mounted in DPX. The pictures were obtained using oil immersion microscope (Nikon Corporation K 12,432) with 10/40X magnification of objective lens.

\subsection{Assessment of oxidative stress}

Evaluation of oxidative stress biomarkers, viz., CAT, GR and SOD was done by following the methodologies of Aebi, 1984; Carlberg and Mannervik, 1985; Kakkar et al., 1984 respectively and previously performed methods in our laboratory (Ratn et al., 2018).

Glutathione (GSH) was estimated by following methodology of Moron et al., 1979 with some modifications. GSH was measured by its reaction with DTNB (5,5'dithio 2-nitrobenzoic acid) (Ellman's reaction) and produces a compound that absorbs light at $412 \mathrm{~nm} .1 \mathrm{~mL}$ of T.E buffer $(1 \mathrm{M}$ Tris $\mathrm{HCl}$ and $0.01 \mathrm{M}$ EDTA) was mixed with $50 \mu \mathrm{l} 0.01 \mathrm{M}$ DTNB and $100 \mu \mathrm{L}$ of tissue homogenate was added and incubated at room temperature for 10 minutes and the absorbance was taken at $412 \mathrm{~nm}$ in a UV-VIS spectrophotometer (Shimadzu, UV-1800 pharma spec). The blank consisted of distilled water instead of tissue homogenate.

\subsection{Statistical analysis}

Each group was executed with three replicates and all were presented as mean \pm standard error mean (S.E.M.). One-way analysis of variance (ANOVA) with Tukey's post hoc test was used to test the significance $(p<0.05)$ of each result in blood, liver and kidney tissue samples of all experimental groups. All data were evaluated by SPSS software (version 20.0, SPSS Company, Chicago, USA).

\section{Results}

\section{1 $\mathrm{LC}_{50}$ of Mercuric chloride $\left(\mathrm{HgCl}_{2}\right)$}

The $96 \mathrm{~h}-\mathrm{LC}_{50}$ value of $\mathrm{HgCl}_{2}$ to $C$. punctatus was estimated to be $0.78 \mathrm{mg} / \mathrm{L}$ with $95 \%$ lower and upper confidence limits of $0.85 \mathrm{mg} / \mathrm{L}$ and $0.72 \mathrm{mg} / \mathrm{L}$ respectively. For sub-lethal treatments, fish were exposed to $1 / 20$ th of $96 \mathrm{~h}-\mathrm{LC}_{50}(0.03 \mathrm{mg} / \mathrm{L})$, and $1 / 10$ th of $96 \mathrm{~h}-\mathrm{LC}_{50}(0.07 \mathrm{mg} / \mathrm{L})$ of $\mathrm{HgCl}_{2}$

\subsection{Physicochemical parameter}

In the test medium i.e.,7 d aged tap water significant physio-chemical parameters $\left(\mathrm{pH}\right.$, temperature $\left({ }^{\circ} \mathrm{C}\right)$, dissolved oxygen (DO), alkalinity and hardness) were recorded before and after completion of 15, 30 and $45 \mathrm{~d}$ of exposure periods, both in control and treated groups (Table 1). All values were found well within the prescribed limits for survival of the fishes (APHA, 2012). 


\subsection{Evaluation of Genotoxicity}

\subsubsection{Micronuclei}

MN frequencies increased significantly $(\mathrm{p}<0.05)$ in erythrocytes of $C$. punctatus after exposure to sublethal test concentrations of mercuric chloride ( $\left.96 \mathrm{~h}-\mathrm{LC}_{50} / 20 ; 0.03 \mathrm{mg} / \mathrm{L}, 96 \mathrm{~h}-\mathrm{LC}_{50} / 10 ; 0.07 \mathrm{mg} / \mathrm{L}\right)$. MN frequency was reported in increasing trend (Fig. 1). The frequencies of $\mathrm{MN}$ of group I were recorded as $0.14 \pm 0.02,0.26 \pm 0.01$ and $0.33 \pm 0.03$ after the exposure periods 15,30 and 45 days respectively. In Group II, treated with $96 \mathrm{~h}-\mathrm{LC}_{50} / 20 ; 0.06 \mathrm{mg} / \mathrm{L}$ were estimated as $0.63 \pm 0.07,1.19 \pm 0.11,1.69 \pm 0.10$ after exposure periods of 15,30 and 45 days respectively. In comparison to control, the frequencies of $\mathrm{MN}$ in group III, treated with $96 \mathrm{~h}-\mathrm{LC}_{50} / 10 ; 0.12 \mathrm{mg} / \mathrm{L}$ were recorded as $0.97 \pm 0.12,1.62 \pm 0.07,2.22 \pm 0.17$ after the exposure periods of 15,30 and 45 days respectively. A significant $(p<0.05)$ increase in micronuclei frequencies were observed in Group III, after every exposure period in comparison to control. The maximum frequency $(2.22 \pm 0.17)$ of micronuclei was recorded in Group III after $45 \mathrm{~d}$ of exposure period. Significant $(p<0.05)$ differences in micronuclei frequencies were also observed among all successive exposure periods 15, 30 and $45 \mathrm{~d}$ in different groups (Fig. 1).

\subsubsection{Nuclear Abnormalities}

The nuclear abnormality (NA) analysis in erythrocytes of $C$. punctatus showed a significantly $(p<0.05)$ higher frequency of alterations including nuclear bud, notched, lobed, blebbed, bifurcated, condensed, karyorrhectic nuclei after exposure to sub-lethal test concentrations of mercuric chloride ( $96 \mathrm{~h}-\mathrm{LC}_{50} / 20$; $0.06 \mathrm{mg} / \mathrm{L}, 96 \mathrm{~h}-\mathrm{LC}_{50} / 10 ; 0.12 \mathrm{mg} / \mathrm{L}$ ). NA frequency was reported in increasing trend (Fig. 2A). The frequencies of NA in group I were recorded as $0.11 \pm 0.01,0.21 \pm 0.01$ and $0.26 \pm 0.01$ after the exposure periods 15,30 and 45 days respectively. In Group II, treated with $96 \mathrm{~h}-\mathrm{LC}_{50} / 20 ; 0.03 \mathrm{mg} / \mathrm{L}$ it was recorded as $0.21 \pm 0.01,0.72 \pm 0.11$ and $1.35 \pm 0.07$ after exposure periods of 15,30 and 45 days respectively. In comparison to control, the frequencies of $\mathrm{NA}$ in group III, treated with $96 \mathrm{~h}-\mathrm{LC}_{50} / 10 ; 0.07 \mathrm{mg} / \mathrm{L}$ were recorded as $0.26 \pm 0.01,1.18 \pm 0.10$ and $1.81 \pm 0.08$ after the exposure periods of 15,30 and 45 days respectively. A significant $(p<0.05)$ increase in nuclear abnormalities were observed in Group III, after every exposure period in comparison to Group I. The maximum frequency $(1.81 \pm 0.08)$ of NA was recorded in Group III after $45 \mathrm{~d}$ of exposure period. Different types of nuclear abnormalities are shown in Fig. 2 (B).

\subsection{Haematological examination}

Haematological parameters viz., RBCs count, WBCs count and $\mathrm{Hb} \%$ of C. punctatus exposed to sub-lethal concentration of $\mathrm{HgCl}_{2}$ at different intervals of exposure (15, 30 and $45 \mathrm{~d}$ ) period were calculated in this study. The blood values of $C$. punctatus, namely the RBC, and $\mathrm{Hb} \%$ were decreased, whereas the WBC level increased significantly $(p<0.05)$ in Group II and Group III as compared to Group I (control) after 15, 30 and $45 \mathrm{~d}$ of exposure period in dose and time dependent manner. 
The results showed that RBC count of $C$. punctatus exposed to sub lethal level of $\mathrm{HgCl}_{2}$ decreased significantly from $1.65 \pm 0.0210 / \mathrm{mm}^{3}$ recorded at control to $1.57 \pm 0.0210 / \mathrm{mm}^{3}$ (Group II) and $1.50 \pm$ $0.0310 / \mathrm{mm}^{3}$ (Group III) after $45 \mathrm{~d}$ of exposure. The values were statistically significant at $(p<0.05)$.

Exposure of $\mathrm{HgCl}_{2}$ has increased the white blood cells count significantly $(\mathrm{p}<0.05)$ from $58.40 \pm 0.2310$ $/ \mathrm{mm}^{3}$ (Group I) to $60.33 \pm 0.0910 / \mathrm{mm}^{3}$ (Group II) and $75.53 \pm 0.2210^{3} / \mathrm{mm}^{3}$ (Group III) at $45 \mathrm{~d}$ of exposure period.

Haemoglobin level was significantly $(p<0.05)$ decreased in different exposure concentrations from 8.10 $\pm 0.06 \mathrm{~g} / \mathrm{dL}$ (Group I) to $6.53 \pm 0.15 \mathrm{~g} / \mathrm{dL}$ (Group II) and $4.53 \pm 0.07 \mathrm{~g} / \mathrm{dL}$ (Group III) after $45 \mathrm{~d}$ of exposure period.

\subsection{Histopathological alterations in liver and kidney}

Mercuric chloride shows remarkable histological alterations in liver and kidney of the test fish Channa punctatus after $45 \mathrm{~d}$ of exposure period.

The histology of kidney shows glomerulus and renal tubules. The recurrent exposure of $\mathrm{HgCl}_{2}$ alter the components of kidney tissue and results in Compact glomerulus (CG), Cavity reduction in renal tubule (CRRT), Hypertrophy (Hy), Necrosis (N), and Vacuolization (V). In Fig. 3, Group I represent the histology of the kidney of the unexposed group. The Group II and III represent the section of exposed group with a reduction in tubular lumens, compact glomerulus and vacuolization in a dose dependant manner. Hypertrophy and necrosis were found only in Group III. However, the histopathological alterations were more definite in group III as shown in Fig. 3. Table 2 shows histological findings in kidney.

The liver histology exhibits of polygonal cells arranged in liver parenchyma with rounded nuclei known as hepatocytes; blood vessels and bile ducts. Histological findings of liver tissue of fish Channa punctatus for control and exposed groups, after $45 \mathrm{~d}$ were represented in Fig. 3. Control group shows no damage in the liver tissue. In Group II and III, the vacuolization, pyknosis and inflammation were recorded in increasing trend in a dose dependant manner; whereas the maximum alterations were observed in Group III, demonstrated by necrosis and inflammation. Table 2 describes the observed histological changes in liver tissue.

\subsection{Oxidative stress estimation in Liver}

Activities of antioxidant enzymes to evaluate the mechanisms of $\mathrm{HgCl}_{2}$ tolerance in Channa punctatus were measured. The effect of $\mathrm{HgCl}_{2}$ on the activity of SOD, CAT, GSH and GR in liver tissue samples is depicted in Fig. 4.

The activities of SOD and CAT in liver tissue of fish in Group II (1/20th 96h-LC 50 ) were not found significant in comparison to Group I after $15 \mathrm{~d}$ of exposure period. However, a significantly $(p<0.05)$ high induction in activities of SOD and CAT was observed in Group III (1/10th 96h-LC 50$)$, after all the exposure 
periods in comparison to Group I. The maximum elevation in activities of SOD and CAT was recorded as $11.85 \pm 0.08$ and $45.49 \pm 0.05$ in Group III after $30 \mathrm{~d}$ of exposure period. Figure 4 displays a significant ( $p$ $<0.05)$ difference in SOD and CAT activities among all successive exposure periods.

The activities of GSH and GR also showed a significant $(p<0.05)$ induction under $\mathrm{HgCl}_{2}$ stress in Group II and Group III after 15 and $30 \mathrm{~d}$ of exposure periods as compared to Group I. The highest activities were recorded as $230.76 \pm 0.39$ and $0.49 \pm 0.00$ in Group III after $30 \mathrm{~d}$ of exposure period. However, a significant $(p<0.05)$ reduction in activities of GSH and GR was recorded as 135. $29 \pm 0.37$ and $0.19 \pm 0.00$ in Group III as compared to control after $45 \mathrm{~d}$ of exposure period as the exposure time extended.

\subsection{Oxidative stress estimation in kidney}

In kidney tissue SOD and CAT activities were found to be significantly $(\mathrm{p}<0.05)$ increased in Group III (1/10th 96 h-LC Lo $_{5}$ ), after every exposure period in comparison to Group I. the highest induction in activities of SOD and CAT was recorded as $8.29 \pm 0.19$ and $37.10 \pm 0.40$ in Group III after $30 \mathrm{~d}$ of exposure period. After $15 \mathrm{~d}$ of exposure period in Group II (1/20th $96 \mathrm{~h}-\mathrm{LC}_{50}$ ) the activities of SOD and CAT in kidney tissue of fish were not found significant in comparison to Group I.

Further, activities of GSH and GR also increased significantly $(p<0.05)$ in Group II and Group III after 15 and $30 \mathrm{~d}$ of exposure periods as compared to Group I. The highest activities were recorded as $223.33 \pm$ 1.11 and $0.45 \pm 0.00$ in Group III after $30 \mathrm{~d}$ of exposure period. However, as the exposure time extended up to 45 days activities of GSH and GR were reduced significantly $(p<0.05)$ and recorded as $116.6 \pm 0.07$ and $0.07 \pm 0.00$ in Group III as compared to control.

\section{Discussion}

This study demonstrates that long term exposure to $\mathrm{HgCl}_{2}$ in fish Channa punctatus triggers the oxidative stress, genotoxicity, haematological and histological impairments in blood, liver and kidney tissues. Relatively small amount of information about effects of long term exposure to $\mathrm{HgCl}_{2}$ is available in literature (Aragão et al., 2018).

The haematological parameters viz., $\mathrm{Hb} \%, \mathrm{RBC}$ and WBC counts may apply to confirm different forms of toxicants because of its strong connection with the environment and often used to identify the physiological status of animals (Kumar et al., 2011). To evaluate the toxicity of $\mathrm{HgCl}_{2}$ in aquatic organisms the genotoxicity, histopathological and biochemical parameters may be utilized as potential biomarkers (Jyotsana et al., 2014; Nagarajan Nagarani et al., 2009; Turkez \& Dirican, 2012; Yadav \& Trivedi, 2009a; Zhang et al., 2016a).

The decrease in $\mathrm{Hb} \%$ shows that the power of fish to supply oxygen to every tissue is confined and this will ultimately lead to slow physical movement (Nussey et al., 1995). Reduction in RBCs is the most common haematological parameter in toxicological investigations that are detected in present research. Decrease in $\mathrm{Hb} \%$ and $\mathrm{RBC}$ level can reveal an anaemic situation (Kulkeaw \& Sugiyama, 2012). This study is in accordance with Panigrahi \& Misra, (1978) who documented that mercury reduces $\mathrm{Hb} \%$ and red 
blood cell count in the fish Anabas scandens. Similarly, RBCs count and $\mathrm{Hb} \%$ was declined in fish Tinca tinca exposed to lead and mercuric chloride (Shah and Altindag, 2004). The decrease in RBCs counts in the present study could have caused due to inhibition of RBCs production by the mercury chloride (Setiyowati et al., 2019). Likewise, Li et al., (2011) documented a declination in total amount of RBC in the blood of Oncorhynchus mykiss when exposed to verapamil, a cardiovascular medicine. Mainly, the decrement in RBC counts in fish could mark the anaemic condition of the fish under stress due to environmental pollution ( $\mathrm{Li}$ et al., 2011). Many studies have documented that heavy metal toxicity decreases the RBCs count. (Al-Asgah et al., 2015; Kumar et al., 2011; Kumar and Banerjee, 2016; Vinodhini and Narayanan., 2009).

WBCs are engaged in the regulation of immunological work in various organisms and increment in WBC count in treated fish shows a common immune response to mercury chloride (Hedayati \& Ghaffari, 2013; Mohamed, 2014). WBCs count may also arises due to the protection mechanism against adverse effect of the xenobiotics on immune system which liberates lymphocytes from lympho myeloid tissue (Ates et al., 2008). Various studies also recorded increased WBC count due to heavy metal exposure (Abdel-Warith et al., 2020; Bujjamma \& Padmavathi, 2018; Singh et al., 2008)

In natural habitats, high concentration of mercury in the liver and kidneys of aquatic organisms were observed (Baby et al., 2011; Friis, 2012; Suhendrayatna et al., 2019; Żarski et al., 2017). $\mathrm{HgCl}_{2}$ strain is considered harmful to the most organisms including fishes because it causes ROS production (Ibrahim, 2015). Consequently, excessive production of ROS leads to oxidative stress in liver and kidney tissues by disturbing the activities of antioxidants which damage the defence processes leading to oxidative damage of lipid membrane, cellular protein, nucleic acid, tissue degeneration and DNA damage (Sharma et al., 2012). Anti-oxidative defence system in every organism comprises the enzymatic scavengers to mitigate overproduction of ROS and fix the impairments caused by them (Birben et al., 2012). Two most common enzymes, liable for removal of ROS are SOD and CAT. Increased superoxide radicals scavenge by SOD enzyme and forms hydrogen per oxide $\left(\mathrm{H}_{2} \mathrm{O}_{2}\right)$ which is further converted to water by the action of CAT enzyme (Matés, 2000). The present study shows increment in SOD and CAT levels in time dependent manner in the liver and kidney tissues. This can be concluded that excess $\mathrm{HgCl}_{2}$ increases the activity of SOD and CAT because the SOD-CAT system provides the first line defence system against toxicants in the body. In a similar study Zhang et al., (2016) found that exposure to $\mathrm{HgCl}_{2}$ induces the activities of SOD and CAT in zebrafish embryos larvae. Jyotsana et al., (2014) in her study on effects of $\mathrm{HgCl}_{2}$ on the antioxidant system in zebra fish showed an increase in catalase activity. Nagarani et al., (2011) also documented that $\mathrm{HgCl}_{2}$ increased oxidative stress in marine fish Terapon jarbua during coastal aquaculture practices.

Glutathione, as a transporter of mercury and an antioxidant, plays three crucial roles in defending the body from mercury toxicity. GSH do not allow mercury to bind to cellular proteins and prevents damage to both enzymes and tissues (Jan et al., 2015). Entry of mercury in tissue cells conversion of mercury in intracellular toxin is also prevented by Glutathione-mercury complex (Drisko, 2018). According to reports 
published $\mathrm{HgCl}_{2}$ at low concentration decreases mitochondrial $\mathrm{GSH}$ and increases $\mathrm{H}_{2} \mathrm{O}_{2}$ formation in rat kidney mitochondria under conditions of damage electron transport chain (Sener et al., 2003). Besides, increase of GSH content may be related to protection against oxidative challenge (Lushchak, 2012). Organisms living in aquatic habitats have high content of GSH that may provide the first line of defence against the influence of toxic heavy metals (Kurutas, 2016) which may be the reason for observed induction in GSH activity.

Estimation of GR activity is also helpful in finding out more oxidative stress caused in the presence of $\mathrm{HgCl}_{2}$. This enzyme provides more GSH by reduction of GSSG (stored) in the body for mitigation of oxidative stress in the body efficiently. Oxidative stress increases the GR activity due to exposure of heavy metals and other pollutants in fish liver and other fish tissues (Stephensen et al., 2002). Mercury enhances the GR activity in catfish liver indicates that GR belongs to the defence system protecting the organism against oxidative stress, as also suggested by Tekman et al., (2008)

On the other hand, chronic exposure of liver and kidney tissues to $\mathrm{HgCl}_{2}$ caused a decrement in $\mathrm{GSH}$ and GR level. This decreased GSH and GR level may be due to a direct binding of $\mathrm{Hg}$ to the GSH or due to an increased oxidation of the thiol group of GSH which would not be reconverted to GSH by GR activity (Ercal et al., 2005). GSH and GR depletion appears to increase the risk of oxidative stress due to alleviated cell protection ability. The findings of this study reveal that $\mathrm{HgCl}_{2}$ induces oxidative stress in liver and kidney tissues which are in accordance with the study of Monteiro et al., (2010) who have documented the adverse effects of $\mathrm{HgCl}_{2}$ on the antioxidant defence mechanism of tropical fresh water fish, Brycon amazonicus.

Metal catalyzation leads to the formation of ROS capable of damaging DNA. Once the oxidative stress exceeds the defence mechanism of antioxidant system, it leads to DNA damage, which is one of the most common causes of genotoxicity (Awasthi et al., 2019). In this study, frequencies of MN and NA are recorded to justify this. This study shows the induction in MN and NA frequencies which directly reflects DNA damage. The mechanisms of MN formation, which can be related to clastogenic and aneugenic events and their significance are well documented (Chondrou et al., 2018; Decordier et al., 2011; Schmid, 1975; Ueda et al., 1992). Ample numbers of investigations are there which have measured induction of $\mathrm{MN}$ by $\mathrm{HgCl}_{2}$ for genotoxicity measurement in fishes (Nagarajan Nagarani et al., 2009; Nirchio et al., 2019; Qureshi, Yaqoob, 2013; Yadav \& Trivedi, 2009) On the other hand, very less studies are available for the utilization of other nuclear anomalies in erythrocytes for the assessment of DNA damage in aquatic organisms (De Souza Azevedo et al., 2012). Over past few years, the concurrent analyses of NA and MN frequencies in blood have received consideration in genotoxic studies. However, the mechanisms responsible for formation of NAs is due to know. Further, various studies have documented that NAs can be induced in response to exposure to genotoxic agents (Braham et al., 2017; De Souza Azevedo et al., 2012; Guilherme et al., 2008; Hoshina et al., 2008; Nirchio et al., 2019). This study provides a proof that NAs may arise in the erythrocytes of fish, Channa punctatus due to oxidative stress induced by $\mathrm{HgCl}_{2}$. Similarly, Ansari et al., (2008) have documented that oxidative stress is responsible for the induction of 
NAs (Lobed nuclei, blebbed nuclei, bilobed nuclei and binucleated nuclei) in erythrocytes of fish Channa punctatus on the exposure of deltamethrin. Çavaş and Ergene-Gözükara, (2005) consider that the exposure to vestiges of petroleum induced lobed and blebbed nuclear abnormalities in fishes. This study shows highly significant and positive relationship with $\mathrm{HgCl}_{2}$ concentration and frequency of micronuclei and other nuclear abnormalities.

Histopathological examination of two major organs responsible for accumulation and elimination of toxicants in fishes, liver and kidney was done to further evaluate the toxic potential of $\mathrm{HgCl}_{2}$. Ample number of data is present regarding metal induced histopathological changes in Piscean species (Álvarez-Muñoz et al., 2009; Hampel et al., 2008; Jabeen et al., 2019; Padrilah et al., 2018). Similarly, Awasthi et al., (2019) have also documented the histopathological alterations as the end-point marker for assessment of toxic potential of heavy metal in liver tissues of fish, Channa punctatus. Our results show histopathological impairments viz., increase in vacuolization $(V)$, pyknosis (Py), necrosis $(N)$, inflammation (In) and hypertrophy (Hy) in liver and the cavity reduction in renal tubules (CRRT), glomerulus degenerative changes (GDC), vacuolization $(V)$ and necrosis $(N)$ in kidney of exposed fishes for both groups (Group II and Group III). Hosseini et al., (2018) have also reported hepatic and renal histopathological damage in rats intoxicated with $\mathrm{HgCl}_{2}$. Similar histopathological changes were observed in liver of fish Danio rerio exposed to $\mathrm{HgCl}_{2}$ ( $\mathrm{Macirella}$ et al., 2016). Reduction in renal tubules and tubular lumens in kidney (Mishra \& Mohanty, (2009) were also reported in fishes exposed to heavy metals. Velma \& Tchounwou, (2011) have also documented similar histopathological lesions in tissues of gold fish induced by chromium.

\section{Conclusion}

Until now, knowledge about oxidative stress induced by $\mathrm{HgCl}_{2}$ and consequent molecular damage in fish tissues is still not well elucidated. Outcomes of this study explains an extensive profile of $\mathrm{HgCl}_{2}$ induced eco-toxicological manifestations in a fish of wider availability. Major outcome of the present investigations includes $\mathrm{HgCl}_{2}$ induced haematological changes, damaged antioxidant defence system in two major organs (liver and kidney) in fishes which leads to increment in MN and NA frequencies, and resulting histo-pathological changes in both the vital organs. Our results give valuable data for a broader understanding of the effects of $\mathrm{HgCl}_{2}$ on fish liver and kidney supporting the strong relationship between genotoxicity and biochemical biomarkers. Further studies are needed to understand the dangerous effects of heavy metals on hepatic and renal tissue in order to have a more comprehensive overview of the impact on aquatic biota.

\section{Declarations}

Acknowledgements 
We record our sincere thanks to the UGC, New Delhi, for providing Special Assistance Programme (SAP) and the Department of Science and Technology, Government of India for providing FIST and PURSE Programs. We are also grateful to the Head of Department of Zoology, University of Lucknow, Lucknow (226007), for providing necessary laboratory facilities.

\section{Compliance with Ethical Standards}

Under the provisions of committee for the purpose of control and supervision of experiments on animals (CPCSEA), Government of India, an Institutional Animal Ethics Committee (IAEC) vide registration no. $1861 / \mathrm{GO} / \mathrm{Re} / \mathrm{S} / 16 / \mathrm{CPCSEA}$ already exists in the University of Lucknow, Lucknow. We have followed the protocols mentioned therein CPCSEA for maintenance and experiment.

\section{Conflict of Interest}

The authors declare that they have no conflict of interest.

\section{References}

A Ibrahim AT (2015). Effects of Mercury Chloride on Oxidative Stress Biomarkers of Some Tissues of the African Catfish Clarias gariepinus (Burchell, 1822). J of Vet Sci \& Tech 06(04):1-5. https://doi.org/10.4172/2157-7579.1000242

Abara PN, Ibiam UA, Udebuani AC (2016). Cytotoxic and Genotoxic Effects of Two Detergents on Rattus norvegicus. Eur J of Appl Sci 8(5):277-281. https://doi.org/10.5829/idosi.ejas.2016.8.5.1142

Abdel-Warith AAW, Younis MES, Al-Asgah NA, Rady AM, Allam H. Y. (2020). Bioaccumulation of lead nitrate in tissues and its effects on hematological and biochemical parameters of Clarias gariepinus. Sau $\mathrm{J}$ of Bio Sci 27(3):840-845. https://doi.org/10.1016/j.sjbs.2020.01.015

Aebi H (1984). Catalase in Vitro. Methods in Enzymology 105(C) 121-126.

https://doi.org/10.1016/S0076-6879(84)05016-3

Ahmad S, Mahmood R (2019). Mercury chloride toxicity in human erythrocytes: enhanced generation of ROS and RNS, hemoglobin oxidation, impaired antioxidant power, and inhibition of plasma membrane redox system. Environ Sci and Pollut R, 26(6):5645-5657. https://doi.org/10.1007/s11356-018-04062-5

Al-Asgah NA, Abdel-Warith AWA, Younis ESM, Allam HY (2015). Haematological and biochemical parameters and tissue accumulations of cadmium in Oreochromis niloticus exposed to various concentrations of cadmium chloride. Sau J of Biol Sci 22(5):543-550.

https://doi.org/10.1016/j.sjbs.2015.01.002

Álvarez-Muñoz D, Gómez-Parra A, Blasco J, Sarasquete C,González-Mazo E (2009). Oxidative stress and histopathology damage related to the metabolism of dodecylbenzene sulfonate in Senegalese sole. Chemosphere 74(9):1216-1223. https://doi.org/10.1016/J.CHEMOSPHERE.2008.11.032 
Anbumani S, Mohankumar MN (2011). Nuclear and Cytoplasmic Abnormalities in the Fish Catla catla (Hamilton) Exposed to Chemicals and Ionizing Radiation. R J of Envir Sci 5(12):867-877. https://doi.org/10.3923/rjes.2011.867.877

Andrianopoulos C, Stephanou G, Demopoulos NA (2006). Genotoxicity of hydrochlorothiazide in cultured human lymphocytes. I. Evaluation of chromosome delay and chromosome breakage. Envir and Mol Muta 47(3):169-178. https://doi.org/10.1002/em.20180

Ansari RA, Kaur M, Ahmad F, Rahman S, Rashid H, Islam F, Raisuddin S (2008). Genotoxic and Oxidative Stress-inducing Effects of Deltamethrin in the Erythrocytes of a Freshwater Biomarker Fish Species, Channa punctata Bloch. Wiley Periodicals, Inc. Environ Toxicol 24:429-436. https://doi.org/10.1002/tox.20445

Ansari R A, Kaur M, Ahmad F, Rahman S, Rashid H, Islam F, Raisuddin S (2009). Genotoxic and oxidative stress-inducing effects of deltamethrin in the erythrocytes of a freshwater biomarker fish species, Channa punctata Bloch. Environmental Toxicology 24(5):429-436. https://doi.org/10.1002/tox.20445

APHA, AWWA, WEF (2012). Standard Methods for the Examination of Water and Wastewater (E. W. Rice, R. B. Baird, A. D. Eaton, \& L. S. Clesceri (eds.); 22nd ed.). APHA 800 I Street, NW, Washington, DC 200013710 .

Aragão WAB, Teixeira FB, Fagundes NCF, Fernandes RM, Fernandes LMP, Da Silva MCF, Amado LL, Sagica FES, Oliveira EHC, Crespo-Lopez ME, Maia CSF, Lima RR (2018). Hippocampal dysfunction provoked by mercury chloride exposure: Evaluation of cognitive impairment, oxidative stress, tissue injury and nature of cell death. Oxi Med and Cell Long 1-11. https://doi.org/10.1155/2018/7878050

Ates B, Orun I, Talas, ZS, Durmaz G, Yilmaz I (2008). Effects of sodium selenite on some biochemical and hematological parameters of rainbow trout (Oncorhynchus mykiss Walbaum, 1792) exposed to $\mathrm{Pb} 2+$ and Cu2+. Fish Physiol and Biochem 34(1):53-59. https://doi.org/10.1007/s10695-007-9146-5

Awasthi Y, Ratn A, Prasad R, Kumar M, Trivedi A, Shukla J P, Trivedi SP (2019). A protective study of curcumin associated with $\mathrm{Cr} 6+$ induced oxidative stress, genetic damage, transcription of genes related to apoptosis and histopathology of fish, Channa punctatus (Bloch, 1793). Environ Toxicol and Pharmacol 71:1-10. https://doi.org/10.1016/j.etap.2019.103209

Awasthi Y, Ratn A, Prasad R, Kumar M, Trivedi SP (2018). An in vivo analysis of $\mathrm{Cr} 6+$ induced biochemical, genotoxicological and transcriptional profiling of genes related to oxidative stress, DNA damage and apoptosis in liver of fish, Channa punctatus (Bloch, 1793). Aqua Toxicol 200:158-167. https://doi.org/10.1016/j.aquatox.2018.05.001

Baby J, Raj J, Biby E, Sankarganesh P, Jeevitha M, Ajisha S, Rajan S (2011). Toxic effect of heavy metals on aquatic environment. Int J of Bio and Chem Sci 4(4). https://doi.org/10.4314/ijbcs.v4i4.62976 
Berg K, Puntervoll P, Valdersnes S, Goksøyr A (2010). Responses in the brain proteome of Atlantic cod (Gadus morhua) exposed to methylmercury. Aqua Toxicol, 100(1), 51-65.

https://doi.org/10.1016/j.aquatox.2010.07.008

Berntssen MHG, Aatland A, \& Handy, R. D (2003). Chronic dietary mercury exposure causes oxidative stress, brain lesions, and altered behaviour in Atlantic salmon (Salmo salar) parr. Aqua Toxicol 65(1):5572. https://doi.org/10.1016/S0166-445X(03)00104-8

Birben E, Sahiner UM, Sackesen C, Erzurum S, Kalayci O (2012). Oxidative stress and antioxidant defense. The World Allergy Organization J 5(1):9-19. https://doi.org/10.1097/WOX.0b013e3182439613

Bleau H, Daniel C, Chevalier G, Van Tra H, Hontela A (1996). Effects of acute exposure to mercury chloride and methylmercury on plasma cortisol, $\mathrm{T} 3, \mathrm{~T} 4$, glucose and liver glycogen in rainbow trout (Oncorhynchus mykiss). Aqua Toxicol 34(3):221-235. https://doi.org/10.1016/0166-445X(95)00040-B

Braham RP, Blazer VS, Shaw CH, Mazik PM (2017). Micronuclei and other erythrocyte nuclear abnormalities in fishes from the Great Lakes Basin, USA. Environ and Mol Mut 58(8):570-581. https://doi.org/10.1002/em.22123

Bujjamma P, Padmavathi P (2018). Effect of cadmium on Haematological changes in a freshwater catfish, Heteropneustes fossilis. Int J of Zool Stud 3(1):132-141. www.zoologyjournals.com

Burress RM (1976). Development and evaluation of on-site toxicity test procedures for fishery investigations (Vol. 68). US Department of the Interior, Fish and Wildlife Service.

Cappello T, Brandão F, Guilherme S, Santos MA, Maisano M, Mauceri A, Canário J, Pacheco M, Pereira P (2016). Insights into the mechanisms underlying mercury-induced oxidative stress in gills of wild fish (Liza aurata) combining $1 \mathrm{H}$ NMR metabolomics and conventional biochemical assays. Sci Total Environ 13-24. https://doi.org/10.1016/j.scitotenv.2016.01.008

Carlberg I, Mannervik, B (1985). [59] Glutathione reductase. Methods in Enzymology, 113(C), 484-490. https://doi.org/10.1016/S0076-6879(85)13062-4

Çavaş T, Ergene-Gözükara S (2005). Induction of micronuclei and nuclear abnormalities in Oreochromis niloticus following exposure to petroleum refinery and chromium processing plant effluents. Aqua Toxicol 74(3):264-271. https://doi.org/10.1016/j.aquatox.2005.06.001

Chondrou V, Trochoutsou K, Panayides A, Efthimiou M, Stephanou G, Demopoulos NA (2018). Combined study on clastogenic, aneugenic and apoptotic properties of doxorubicin in human cells in vitro. $\mathrm{J}$ of Bio R-Thessa 25(1). https://doi.org/10.1186/s40709-018-0089-z

Crump KL, Trudeau VL (2009). Mercury-induced reproductive impairment in fish. Environ Toxicol and Chem 28(5):895-907. https://doi.org/10.1897/08-151.1 
Dash HR, Das S (2015). Bioremediation of inorganic mercury through volatilization andbiosorption by transgenic Bacillus cereus BW-03(p PW-05). Int Biodeterior and Biodegradation 103:179-185. https://doi.org/10.1016/j.ibiod.2015.04.022

de Jesus TB, de Almeida PGA, Vergílio CdosS, Machado ALdos S, de Carvalho CEV (2011). Acute intraperitoneal mercury chloride contamination and distribution in liver, muscle and gill of a neotropical fish Hoplias malabaricus (BLOCK, 1794). Braz Arch Biol and Tech 54(2):379-386.

https://doi.org/10.1590/S1516-89132011000200021

De Souza Azevedo J, De Santis Braga E, Alberto C, Ribeiro O (2012). Nuclear abnormalities in erythrocytes and morphometric indexes in the catfish cathorops spixii (ariidae) from different sites on the southeastern brazilian coast. Braz J of oceanograph (Vol. 60, Issue 3).

Decordier I, Mateuca R, Kirsch-Volders M (2011). Micronucleus assay and labeling of centromeres with FISH technique. Meth in mol bio (Clifton, N.J.) (Vol. 691, pp. 115-136). https://doi.org/10.1007/978-160761-849-2_7

Drisko JA (2018). Chelation Therapy. In Integrative Medicine: Fourth Edition (pp. 1004-1015.e3). Elsevier. https://doi.org/10.1016/B978-0-323-35868-2.00107-9

Dwivedi S, Kumar M, Trivedi SP (2017). Mitigating potential of Melissa officinale against As 3+-induced cytotoxicity and transcriptional alterations of Hsp70 and Hsp27 in fish, Channa punctatus (Bloch). Environ Monit Assess 189(306) 1-15. https://doi.org/10.1007/s10661-017-6002-7

Finney DJ (1971). Statistical logic in the monitoring of reactions to therapeutic drugs. Meth info in med 10(04):237-245.

Friis HR. (2012). The Praeger Handbook of Environmental Health (Vol. 3).

Godkar PB, Godkar DP. (2003) Routine Haematological Tests. Textbook of Medical Laboratory Technology, 2nd Edition, ISBN: 81-85578-58-3, Published by Bhalani Publishing House, Mumbai, India $2003 ; 738-742$.

Gonzalez P, Dominique Y, Massabuau J C, Boudou A, Bourdineaud JP (2005). Comparative effects of dietary methylmercury on gene expression in liver, skeletal muscle, and brain of the zebrafish (Danio rerio). Environ Sci and Tech 39(11):3972-3980. https://doi.org/10.1021/es0483490

Guilherme S, Válega M, Pereira ME, Santos M A, Pacheco M (2008). Erythrocytic nuclear abnormalities in wild and caged fish (Liza aurata) along an environmental mercury contamination gradient. Ecotoxico Environ Saf 70(3):411-421. https://doi.org/10.1016/j.ecoenv.2007.08.016

Hampel M, Ortiz-Delgado JB, Sarasquete C, Blasco J (2008). Effects of sediment sorbed linear alkylbenzene sulphonate on juveniles of the Senegal sole, Solea senegalensis: toxicity and histological indicators. Histol and Histopath 23(1):87-100. https://doi.org/10.14670/HH-23.87 
Hedayati A, Ghaffari Z (2013). Effect of Mercuric Chloride on Some Hematological, Biochemical Parameters in Silver Carp (Hypophthalmichthys Molitrix). International Journal of Veterinary Medicine: R \& Reports October 1-11. https://doi.org/10.5171/2013.183410

Hoshina MM, de Angelis DdeF, Marin-Morales MA (2008). Induction of micronucleus and nuclear alterations in fish (Oreochromis niloticus) by a petroleum refinery effluent. Mut Res-Gen Tox En 656(12):44-48. https://doi.org/10.1016/j.mrgentox.2008.07.004

Hosseini A, Rajabian A, Fanoudi S, Farzadnia M, Boroushaki MT (2018). Protective effect of Rheum turkestanicum root against mercuric chloride-induced hepatorenal toxicity in rats. Avicenna $\mathrm{J}$ Phytomedicine 8(6):488-497. http://www.ncbi.nlm.nih.gov/pubmed/30456196

Jabeen G, Farkhanda M, Javid A, Azmat H, Arshad M, Fatma S (2019). Evaluation of Fish Health Status and Histopathology in Gills and Liver Due to Metal Contaminated Sediments Exposure. Bull Environ Contam Toxicol 100:492-501. https://doi.org/10.1007/s00128-018-2295-7

Jan AT, Azam M, Siddiqui K, Ali A, Choi I, Haq QMR (2015). Heavy metals and human health: Mechanistic insight into toxicity and counter defense system of antioxidants. Int J Mol Sci (Vol. 16, Issue 12, pp. 29592-29630). MDPI AG. https://doi.org/10.3390/ijms161226183

Javed M (2015). Heavy Metal Contamination of Freshwater Fish and Bed Sediments in the River Ravi Stretch and Related Tributaries. October 2005. https://doi.org/10.3923/pjbs.2005.1337.1341

Jyotsana Madeshia A, Prabasheela B (2014). Mercuric Chloride Toxicity and Its Influence on Enzymatic Antioxidants - A Study on Zebra Fish Model (Danio rerio). Brit J Appl Sci \& Tech 4(28):4130-4135. https://doi.org/10.9734/bjast/2014/10374

Kakkar P, Das B, Viswanathan P (1984). A Modified Spectrophotometric Assay of Superoxide Dismutase. Ind J Biochem \& Biophy Val, 130-132.

Kimáková T, Kuzmová L, Nevolná Z, Bencko V (2018). Fish and fish products as risk factors of mercurexposure. Ann Agric Environ Med 25(3):488-493. https://doi.org/10.26444/aaem/84934

Kulkeaw K, Sugiyama D (2012). Zebrafish erythropoiesis and the utility of fish as models of anemia. Stem Cel/ Res Ther. 3 6:55. https://doi.org/10.1186/scrt146

Kumar A, Nagpure PNS, Trivedi SP (2011). Haematological responses in a freshwater fish Channa punctatus (Bloch) exposed to profenofos. Nat Aca Sci Lett 34:(9-10)

Kumar M, Gupta N, Ratn A, Yashika A, Prasad R, Trivedi A, Trivedi PS (2019). Biomonitoring of Heavy Metals in River Ganga Water, Sediments, Plant, and Fishes of Different Trophic Levels. Biol Trace Elem Res 1-12. https://link.springer.com/content/pdf/10.1007\%2Fs12011-019-01736-0.pdf 
Kumar R, Banerjee TK (2016). Arsenic induced hematological and biochemical responses in nutritionally important catfish Clarias batrachus (L.). Toxicol Reports 3:148-152.

https://doi.org/10.1016/j.toxrep.2016.01.001

Kumar SP (2012). Micronucleus assay: a sensitive indicator for aquatic pollution. Int $\mathrm{J}$ of R in BioSci $1(2): 32-37$.

Kumari K, Khare A, Dange S (2014). The applicability of oxidative stress biomarkers in assessing chromium induced toxicity in the fish Labeo rohita. BioMed R Int 2014, 782493.

https://doi.org/10.1155/2014/782493

Kurutas EB (2016). The importance of antioxidants which play the role in cellular response against oxidative/nitrosative stress: Current state. Nutri J (Vol. 15, Issue 1, p. 71). BioMed Central Ltd. https://doi.org/10.1186/s12937-016-0186-5

Li ZH, Velisek J, Zlabek V, Grabic R, Machova J, Kolarova J, Li P, Randak T (2011). Chronic toxicity of verapamil on juvenile rainbow trout (Oncorhynchus mykiss): Effects on morphological indices, hematological parameters and antioxidant responses. J Hazardous Mat, 185(2-3):870-880. https://doi.org/10.1016/j.jhazmat.2010.09.102

Livingstone DR (2001). Contaminant-stimulated reactive oxygen species production and oxidative damage in aquatic organisms. Marine Pollut Bull Vol. 42 8:656-666. https://doi.org/10.1016/S0025326X(01)00060-1

Łuczyńska J, Łuczyński MJ, Paszczyk B (2016). Assessment of mercury in muscles, liver and gills of marine and freshwater fish. J of Elementol 21(1):113-129. https://doi.org/10.5601/jelem.2015.20.2.879

Lushchak V I (2012). Glutathione Homeostasis and Functions: Potential Targets for Medical Interventions. J of Amino Acids, 2012, 1-26. https://doi.org/10.1155/2012/736837

Macirella R, Guardia A, Pellegrino D, Bernabò I, Tronci V, Ebbesson LOE, Ebbesson LOE, Tripepi S, Brunelli $E$ (2016). Effects of two sublethal concentrations of mercury chloride on the morphology and metallothionein activity in the liver of zebrafish (Danio rerio). Int J Mol Sci 17(3):361. https://doi.org/10.3390/ijms17030361

Mahboob S, Fares H, Al-Balwai A, Al-Misned F, Ahmad Z (2013). Investigation on the Genotoxicity of Mercuric Chloride to Freshwater Clarias gariepinus. Pak Veter J 34(1):100-103. www.pvj.com.pk

Matés JM (2000). Effects of antioxidant enzymes in the molecular control of reactive oxygen species toxicology. Toxicol (Vol. 153). www.elsevier.com/locate/toxicol

Mela M, Randi MAF, Ventura DF, Carvalho CEV, Pelletier E, Oliveira Ribeiro CA (2007). Effects of dietary methylmercury on liver and kidney histology in the neotropical fish Hoplias malabaricus. Ecotoxico Environ Saf 68(3):426-435. https://doi.org/10.1016/j.ecoenv.2006.11.013 
Mela M, Neto FF, Yamamoto FY, Almeida R, Grötzner SR, Ventura DF, de Oliveira Ribeiro CA (2014). Mercury distribution in target organs and biochemical responses after subchronic and trophic exposure to Neotropical fish Hoplias malabaricus. Fish Physiol Biochem 40(1):245-256.

https://doi.org/10.1007/s10695-013-9840-4

Minoia C, Ronchi A, Pigatto P, Guzzi G (2009). Effects of mercury on the endocrine system. Critical Reviews Toxicol 39(6), 538. https://doi.org/10.1080/10408440903057029

Mishra AK, Mohanty B (2009). Chronic exposure to sublethal hexavalent chromium affects organ histopathology and serum cortisol profile of a teleost, Channa punctatus (Bloch). Sci Total Environ 407(18):5031-5038. https://doi.org/10.1016/j.scitotenv.2009.05.042

Mishra N, Pandey PK, Datta Munshi JS, Singh BR (1977). Haematological parameters of an air-breathing mud eel, Amphipnous cuchia (Ham.) (Amphipnoidae; Pisces). J of Fish Bio 10(6):567-573. https://doi.org/10.1111/j.1095-8649.1977.tb04089.x

Mohamed W (2014). Selective Evaluation of Certain Blood and Biochemical Parameters of Egyptian Catfish (Clarias Lazera) Exposed to Mercuric Chloride With Particular Reference to Erythrocyte Morphological Anomalies. Int Blood R Reviews 2(5):222-234. https://doi.org/10.9734/ibrr/2014/11214

Monteiro DA, Rantin FT, Kalinin AL (2010). Inorganic mercury exposure: Toxicological effects, oxidative stress biomarkers and bioaccumulation in the tropical freshwater fish matrinxã, Brycon amazonicus (Spix and Agassiz, 1829). Ecotoxicol 19(1):105-123. https://doi.org/10.1007/s10646-009-0395-1

Morcillo P, Esteban MA, Cuesta A (2017). Mercury and its toxic effects on fish. AIMS Environ Sci 4(3):386-402. https://doi.org/10.3934/environsci.2017.3.386

Moron SM, Depierre WJ, Mannervik B (1979). Levels of glutathione-S-transferase activities in rat lung and liver. Biochimica et Biophysica Acta 582:67-78. https://www.researchgate.net/publication/281266409

Nagarani N, Devi VJ, Kumaraguru AK (2011). Mercuric chloride induced proteotoxicity and structural destabilization in marine fish (therapon jarbua). Toxicol Environ Chem 93(2):296-306.

https://doi.org/10.1080/02772248.2010.512812

Nagarani Nagarajan Devi VJ, Devi CA, Kumaraguru AK (2009). Genotoxicity Assessment of mercuric chloride in the marine fish Therapon jaruba. Environ Asia 2(2):50-54.

https://doi.org/10.14456/ea.2009.16

Nirchio, M., Choco-Veintimilla, O., Quizhpe-Cordero, P. F., Hernández, J. G., \& Oliveira, C. (2019). Genotoxic effects of mercury chloride on the Neotropical fish Andinoacara rivulatus (Cichlidae: Cichlasomatini). Rev Biol Trop Int J Trop Biol 67:4.

Nuran Ercal BSP, Hande Gurer-Orhan BSP, Nukhet Aykin-Burns BSP (2005). Toxic Metals and Oxidative Stress Part I: Mechanisms Involved in Me-tal induced Oxidative Damage. Curr Top Med Chem 6:529-539. 
Nussey G, Van Vuren JHJ, du Preez HH (1995). Effect of copper on the haematology and osmoregulation of the Mozambique tilapia, Oreochromis mossambicus (Cichlidae). Comp. Biochem. Physiol. C Toxicol. Pharmacol. 111(3):369-380. https://doi.org/10.1016/0742-8413(95)00063-1

OECD (2019). Test No. 203: Fish, Acute Toxicity Testing, Section 2: Effects on Biotic Systems. Guidelines for the Testing of Chemicals 203:10. https://doi.org/10.1787/9789264069961-en.

Olayode OA, Daniyan MO, Olayiwola G (2020). Biochemical, hematological and histopathological evaluation of the toxicity potential of the leaf extract of Stachytarpheta cayennensis in rats. J Trad Complement Med 10(6):544-554. https://doi.org/10.1016/j.jtcme.2019.05.001

Padrilah, S. N., Khalizan Sabullah, M., Yunus, M., Shukor, A., Yasid, N. A., Shamaan, N. A., \& Ahmad, S. A. (2018). Toxicity Effects of Fish Histopathology on Copper Accumulation. Pertanika J. Trop. Agric. Sci, 41(2):519-540. http://www.pertanika.upm.edu.my/

Pal M, Ghosh S, Mukhopadhyay M, Ghosh M (2012). Methyl mercury in fish - A case study on various samples collected from Ganges river at West Bengal. Environ Monit Assess 184(6):3407-3414. https://doi.org/10.1007/s10661-011-2193-5

Palermo FF, Risso WE, Simonato JD, Martinez CBR (2015). Bioaccumulation of nickel and its biochemical and genotoxic effects on juveniles of the neotropical fish Prochilodus lineatus. Ecotoxicol Environ Saf 116:19-28. https://doi.org/10.1016/j.ecoenv.2015.02.032

Pandey G (2012). Contamination of Mercury in Fish and Its Toxicity To Both Fish and Humans: an Overview. Int Res J Pharm 3(11):44-47.

Panigrahi AK, Misra BN (1978). Toxicological effects of mercury on a freshwater fish, Anabas scandens, Cuv. \& Val. and their ecological implications. Environ Pollut (1970) 16(1):31-39.

https://doi.org/10.1016/0013-9327(78)90135-0

Peressutti SR, Olivera NL, Babay PA, Costagliola M, Alvarez HM (2008). Degradation of linear alkylbenzene sulfonate by a bacterial consortium isolated from the aquatic environment of Argentina. $J$ Appl Microbio 105(2):476-484. https://doi.org/10.1111/j.1365-2672.2008.03771.x

Perveen S, Hashmi I, Khan R (2019). Evaluation of genotoxicity and hematological effects in common carp (Cyprinus carpio) induced by disinfection by-products. J Water Health 17(5):762-776. https://doi.org/10.2166/wh.2019.261

Pushkar B, Sevak P, Singh A (2019). Bioremediation treatment process through mercury-resistant bacteria isolated from Mithi river. Applied Water Science 9(4):1-10. https://doi.org/10.1007/s13201-019-0998-5

Qureshi Yaqoob E (2013). Pak Vet J 8318(2) 85-92. http://www.pvj.com.pk/pdf-files/31_3/192-194.pdf 
Ratn A, Awasthi Y, Kumar M, Singh S K, Tripathi R, Trivedi SP (2017). Phorate induced oxidative stress, DNA damage and differential expression of p53, apaf-1 and cat genes in fish, Channa punctatus (Bloch, 1793). Chemosphere. https://doi.org/10.1016/j.chemosphere.2017.05.008

Ratn A, Prasad R, Awasthi Y, Kumar M, Misra A, Trivedi S P (2018). Zn 2+ induced molecular responses associated with oxidative stress, DNA damage and histopathological lesions in liver and kidney of the fish, Channa punctatus (Bloch, 1793). Ecotoxicol Environ Saf 151:10-20.

https://doi.org/10.1016/j.ecoenv.2017.12.058

Régine MB, Gilles D, Yannick D, Alain B (2006). Mercury distribution in fish organs and food regimes: Significant relationships from twelve species collected in French Guiana (Amazonian basin). Sci Total Environ 368(1):262-270. https://doi.org/10.1016/j.scitotenv.2005.09.077

Rice KM, Walker EM, Wu M, Gillette C, Blough ER (2014). Environmental Mercury and Its Toxic Effects. J Prev Med Public Health, 47. https://doi.org/10.3961/jpmph.2014.47.2.74

Sastry KV, Sharma K (1980). Mercury induced haematological and biochemical anomalies in Ophiocephalus (Channa) punctatus. Toxicol Lett 5(3-4):245-249. https://doi.org/10.1016/03784274(80)90067-3

Sastry KV, Rao DR(1981). Enzymological and biochemical changes produced by mercuric chloride in a teleost fish, Channa punctatus. Toxicol Lett 9(4):321-326. https://doi.org/10.1016/0378-4274(81)900047

Schmid W. (1975). The micronucleus test. Mutation Research/Environmental Mutagenesis and Related Subjects 31(1):9-15. https://doi.org/10.1016/0165-1161(75)90058-8

Sener G, Sehirli AO, Ayanoglu-Dulger G (2003). Melatonin Protects Against Mercury(II)-Induced Oxidative Tissue Damage in Rats. Pharmacol and Toxicol 93(6):290-296. https://doi.org/10.1111/j.16000773.2003.pto930607.x

Setiyowati I, Suprapto H, Mahasri G (2019). The Effects of Mercury Chloride $(\mathrm{Hgcl} 2)$ on the Changes in Hematology and Blood Sugar Level in Carps . Earth Environ. Sci 236:1-11. https://doi.org/10.1088/1755$1315 / 236 / 1 / 012104$

Shah SL, Altindag A (2004). Hematological parameters of tench (Tinca tinca L.) after acute and chronic exposure to lethal and sublethal mercury treatments. Bull Environ Contam Toxicol 73(5):911-918. https://doi.org/10.1007/s00128-004-0513-y

Shahjahan M, Khatun MS, Mun MM, Islam SMM, Uddin MH, Badruzzaman M, Khan S (2020). Nuclear and Cellular Abnormalities of Erythrocytes in Response to Thermal Stress in Common Carp Cyprinus carpio. Front Physiol 11:543. https://doi.org/10.3389/fphys.2020.00543 
Sharma P, Jha AB, Dubey RS, Pessarakli M (2012). Reactive Oxygen Species, Oxidative Damage, and Antioxidative Defense Mechanism in Plants under Stressful Conditions. J of Botany 1-26.

https://doi.org/10.1155/2012/217037

Shukla A, Trivedi SP (2019). Anionic detergent induced DNA damage in fish channa punctatus (Bloch,1793). 8(1):92-96. https://doi.org/10.5829/idosi

Siddiqui E, Pandey J (2019). Assessment of heavy metal pollution in water and surface sediment and evaluation of ecological risks associated with sediment contamination in the Ganga River: a basin-scale study. Environ Sci Pollut Res 26(11):10926-10940. https://doi.org/10.1007/s11356-019-04495-6

Singh D, Nath K, Trivedi SP, Sharma Y (2008). Impact of copper on haematological profile of freshwater fish, Channa punctatus. J Environ Bio 29(2):253-257.

http://jeb.co.in/journal_issues/200803_mar08/paper_25.pdf

Souza-Araujo J, Giarrizzo T, Lima MO, Souza MBG (2016). Mercury and methyl mercury in fishes from Bacajá River (Brazilian Amazon): evidence for bioaccumulation and biomagnification. J Fish Biol 89(1): 249-263. https://doi.org/10.1111/jfb.13027

Stephensen E, Sturve J, Förlin L (2002). Effects of redox cycling compounds on glutathione content and activity of glutathione-related enzymes in rainbow trout liver. Comp Biochem Phys C: Toxicol Pharmacol 133(3): 435-442. https://doi.org/10.1016/S1532-0456(02)00129-1

Suhendrayatna S, Arahman N, Sipahutar LW, Rinidar R, Elvitriana E (2019). Toxicity and Organ Distribution of Mercury in Freshwater Fish (Oreochromis niloticus) after Exposure to Water Contaminated Mercury (Hgll). https://doi.org/10.3390/toxics7040058

Tekman B, Ozdemir H, Senturk M, Ciftci M (2008). Purification and characterization of glutathione reductase from rainbow trout (Oncorhynchus mykiss) liver and inhibition effects of metal ions on enzyme activity. Comp Biochem Phys C: Toxicol Pharmacol 148(2):117-121.

https://doi.org/10.1016/j.cbpc.2008.04.005

Turkez H, Dirican E (2012). A modulator against mercury chloride-induced genotoxic damage: Dermatocarpon intestiniforme (L.). Toxicol Ind Health 28(1), 58-63.

https://doi.org/10.1177/0748233711404036

Ueda T, Hayashi M, Ohtsuka Y, Nakamura T, Kobayashi J, Sofuni T (1992). A Preliminary study of the micronucleus test by acridine orange fluorescent staining compared with chromosomal aberration test using fish erythropoietic and embryonic cells. In Wal. Sci. Tech (Vol. 25). https://iwaponline.com/wst/article-pdf/25/11/235/102661/235.pdf

Vasanthi N, Muthukumaravel K, Sathick O, Sugumaran J (2019). Toxic effect of mercury on the freshwater fish oreochromis mossambicus. Res J life sci bioinform pharm chem sci 5(3):365 376. 
Velkova-Jordanoska L, Kostoski G (2005). Histopathological analysis of liver in fish (Barbus meridionalis petenyi Heckel). Reservoir Trebeništa. Natura Croatica 14(2):147-153.

Velma V, Tchounwou PB (2011). Hexavalent chromium-induced multiple biomarker responses in liver and kidney of goldfish, Carassius auratus. Environ Toxicol 26(6):649-656. https://doi.org/10.1002/tox.20602

Vinodhini R, Narayanan M (2009). The impact of toxic heavy metals on the hematological parameters in common carp (Cyprinus carpio I.). Iran. J. Environ. Health. Sci. Eng, 6(1), 23-28.

http://www.bioline.org.br/pdf?se09005

Wintrobe MM (1967). “Clinical Hematology,” p. 448. Henry Kimpton, London.

Yadav KK, Trivedi SP (2009a). Sublethal exposure of heavy metals induces micronuclei in fish, Channa punctata. Chemosphere 77(11):1495-1500. https://doi.org/10.1016/j.chemosphere.2009.10.022

Yadav KK, Trivedi SP (2009b). Chromosomal aberrations in a fish, Channa punctata after in vivo exposure to three heavy metals. Mutat Res-Gen Tox En 678(1):7-12.

https://doi.org/10.1016/j.mrgentox.2009.05.021

Yong Ung C, Hong Lam S, Myintzu Hlaing M, Lanny Winata C, Korzh S, Mathavan S, Gong Z (2010). Mercury-induced hepatotoxicity in zebrafish: in vivo mechanistic insights from transcriptome analysis, phenotype anchoring and targeted gene expression validation. BMC Genomics 11.

https://doi.org/10.1186/1471-2164-11-212

Żarski JF, Skibniewski M, Skibniewska E, Żarski TP, Majdecka T (2017). The Presence of Mercury in the Tissues of Mallards (Anas platyrhynchos L.) from Włocławek Reservoir. Poland. Biol Trace Elem Res 176(2):384-390. https://doi.org/10.1007/s12011-016-0845-6

Zhang QF, Li YW, Liu ZH, Chen QL (2016). Exposure to mercuric chloride induces developmental damage, oxidative stress and immunotoxicity in zebrafish embryos-larvae. Aquat Toxicol 181:76-85. https://doi.org/10.1016/j.aquatox.2016.10.029

\section{Tables}

Table 1. Physicochemical parameters of test medium 


\begin{tabular}{|llllll|}
\hline Physicochemical parameters & Groups & \multicolumn{4}{c|}{ Exposure periods (In days) } \\
\hline pH & & 0 & 15 & 30 & 45 \\
\hline & Group I & 7.1 & 7.1 & 6.9 & 7 \\
\hline & Group II & 7.1 & 7.2 & 7.2 & 7.3 \\
\hline Temperature $\left({ }^{0} \mathrm{C}\right)$ & Group III & 7 & 7.3 & 7.4 & 7.4 \\
\hline & Group I & 26.2 & 26.3 & 26.2 & 27.3 \\
\hline & Group II & 26.5 & 26.7 & 27.2 & 28.5 \\
\hline Dissolved oxygen $(\mathrm{mg} / \mathrm{L})$ & Group III & 27.2 & 27.9 & 28.6 & 29.3 \\
\hline & Group I & 7.19 & 7.06 & 7.04 & 6.91 \\
\hline Group II & 7.09 & 7.05 & 7.06 & 6.82 \\
\hline Hardness $(\mathrm{mg} / \mathrm{L})$ & Group III & 7.14 & 7.1 & 6.8 & 6.9 \\
\hline & Group I & 72.78 & 73.2 & 74.28 & 75.38 \\
\hline Group II & 72.84 & 73.64 & 74.47 & 76.26 \\
\hline Alkalinity (mg/L) & Group III & 73.64 & 74.54 & 75.67 & 76.89 \\
\hline & Group I & 79.8 & 79.7 & 79.6 & 78.2 \\
\hline Group II & 78.6 & 78.7 & 76 & 75.2 \\
\hline Group III & 79.3 & 78.4 & 76.3 & 75.1 \\
\hline
\end{tabular}

Table 2. The statistical analysis of histological alterations induced by Mercuric chloride in liver and kidney of $C$. punctatus. 


\begin{tabular}{|llll|}
\hline Parameters & Group I & Group II & Group III \\
\hline Liver & & & \\
Vacuolization (V) & - & $2 x$ & $5 x$ \\
Inflammation (In) & - & - & $2 x$ \\
Pyknotic nuclei (PN) & - & $1 x$ & $4 x$ \\
Necrosis (N) & - & $1 x$ & $3 x$ \\
Kidney & - & & \\
Cavity reduction in renal tubule (CRRT) & - & $2 x$ & $5 x$ \\
Compact Glomerulus (CG) & - & $2 x$ & $5 x$ \\
Necrosis (N) & - & - & $3 x$ \\
Vacuolization (V) & - & $3 x$ & $3 x$ \\
Hypertrophy (Hy) & - & - & $3 x$ \\
\hline
\end{tabular}

None-, mild $\mathrm{x}$, moderate $\mathrm{xx}$, strong $\mathrm{xxx}$

\section{Figures}




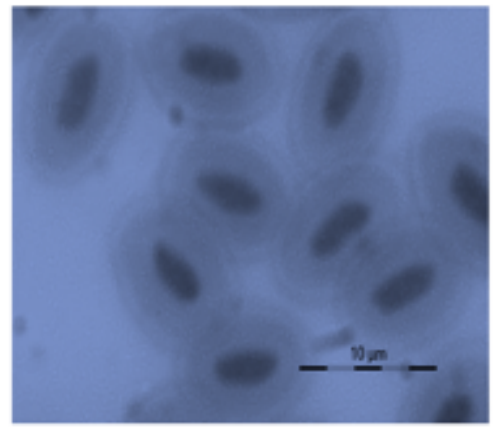

Group I

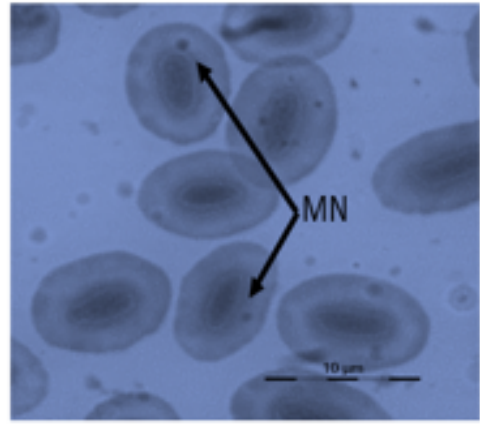

Group II

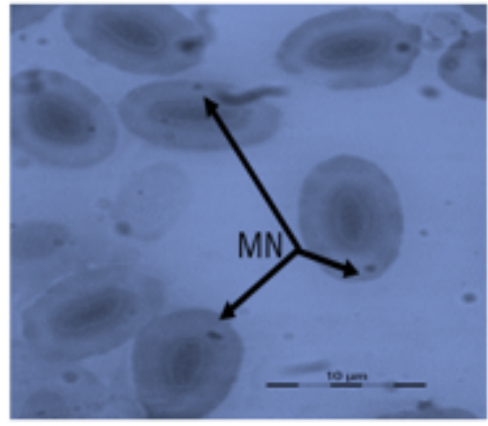

Group III

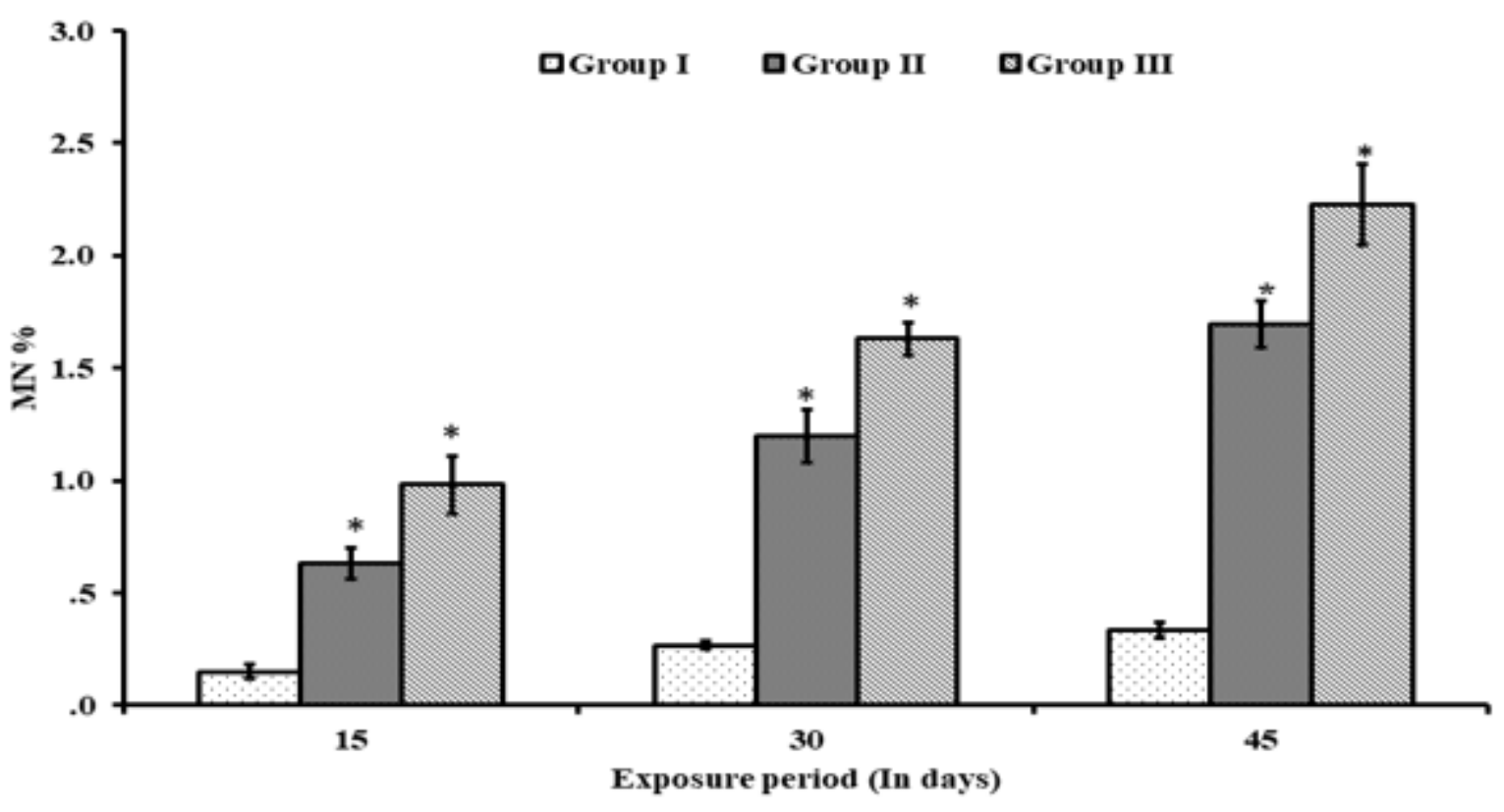

Figure 1

Micronuclei frequency induced by Mercuric chloride in groups (Group II-96 h-LC50/20; $0.03 \mathrm{mg} / \mathrm{L}$ and Group III- 96 h-LC50/10; $0.07 \mathrm{mg} / \mathrm{L}$ ) as compared to control group (Group I) for 15, 30 and $45 \mathrm{~d}$ of exposure periods. (Mean $\pm S D, n=3$ fishes of three replicates of each group). (*represent the significant ( $p$ $<0.05$ ) difference from control). Micrographs of micronuclei at 100X magnification. 
(A)

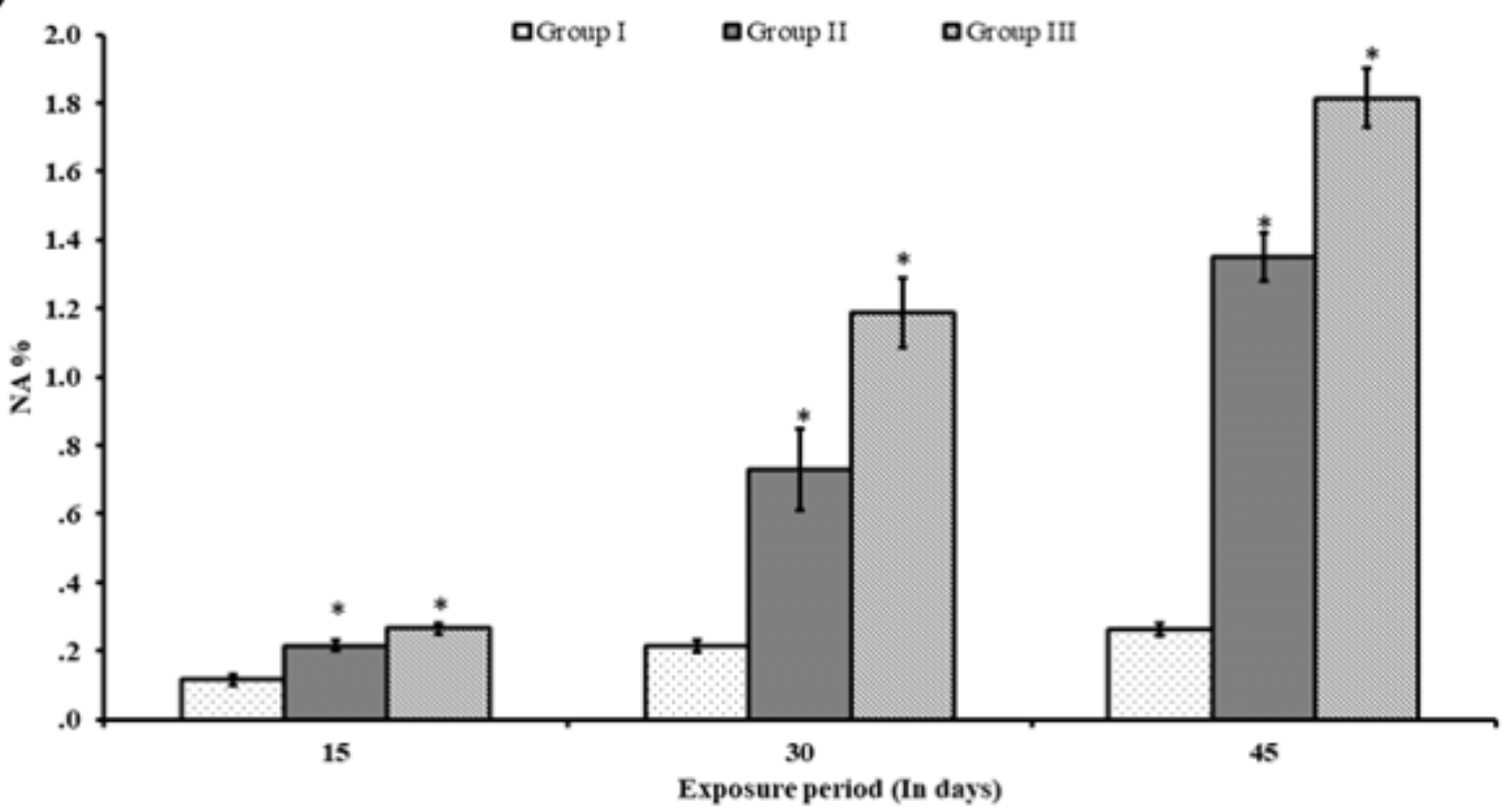

(B)

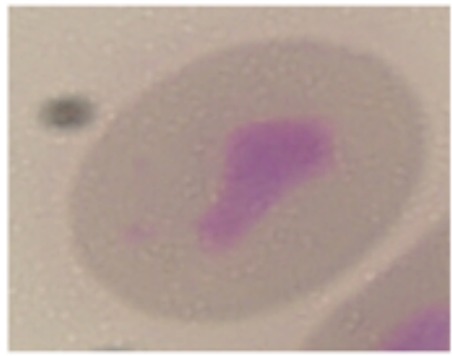

Notched nuclei

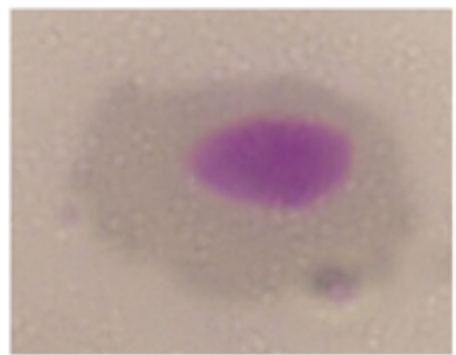

Condensed nuclei

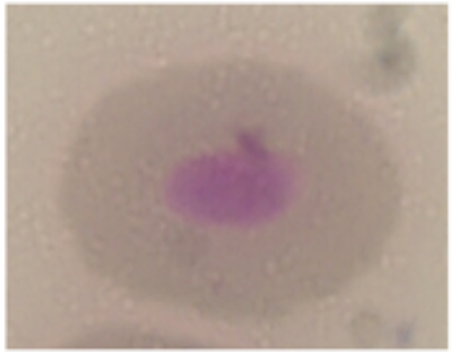

Nuclear bud

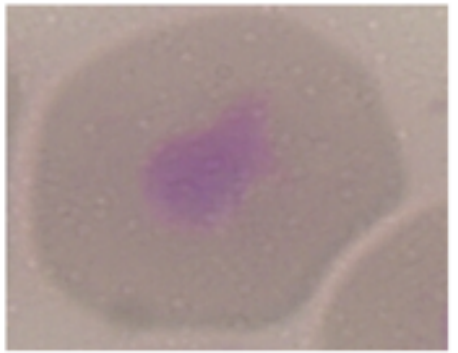

Bifurcated nuclei

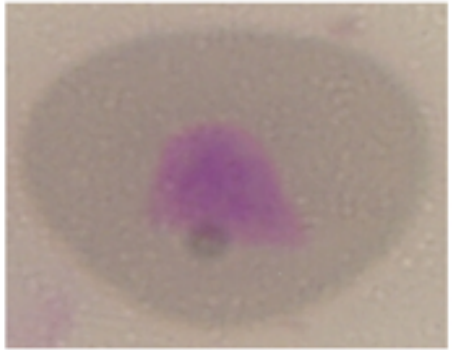

blebbed nuclei

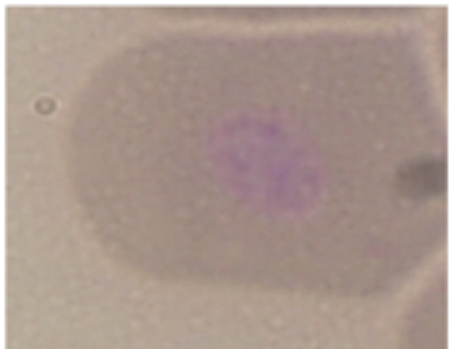

Karyorrhectic nuclei

Figure 2

(A) Nuclear abnormalities frequency induced by Mercuric chloride in groups (Group II-96 h-LC50/20; 0.03 $\mathrm{mg} / \mathrm{L}$ and Group III- $96 \mathrm{~h}-\mathrm{LC} 50 / 10 ; 0.07 \mathrm{mg} / \mathrm{L}$ ) as compared to control group for 15, 30 and $45 \mathrm{~d}$ of exposure periods. (B) Microphotograph showing Nuclear abnormalities in fish erythrocytes at $100 \mathrm{X}$ magnification. (Mean $\pm S D, n=3$ fishes of three replicates of each group). (*represent the significant $(p<$ $0.05)$ difference from control). 


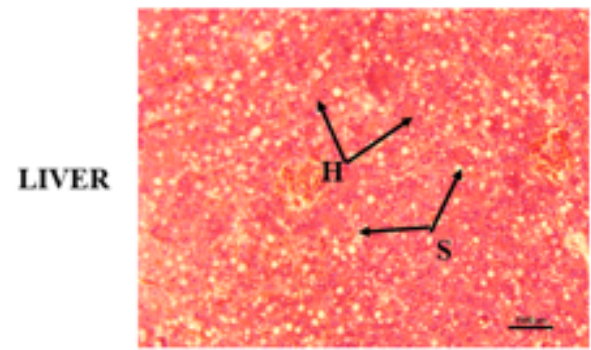

Group I

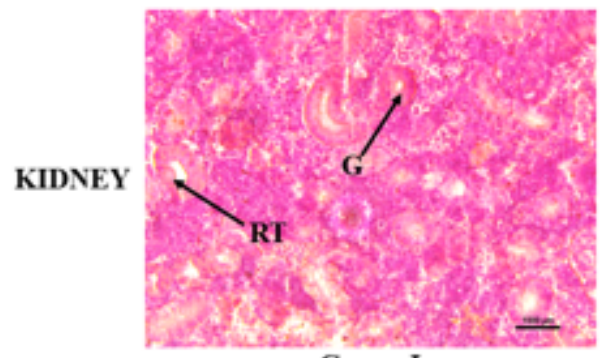

Group I

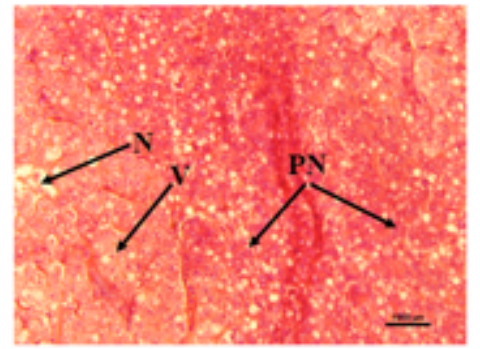

Group II

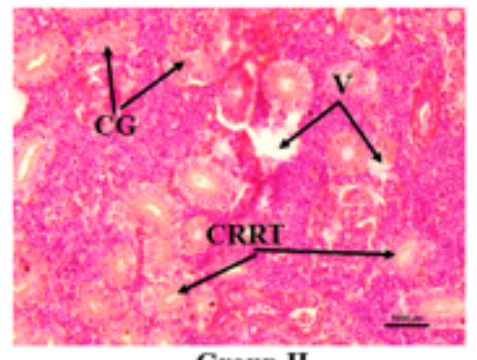

Group II

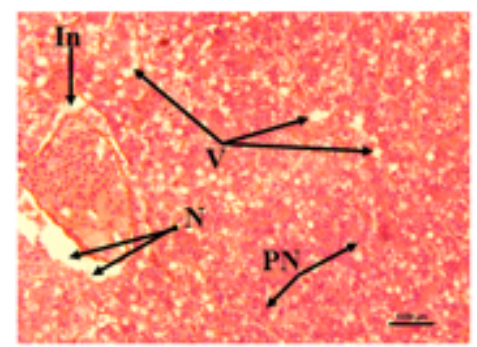

Group III

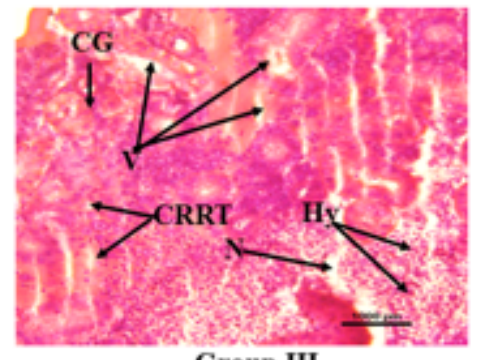

Group III

\section{Figure 3}

Microphotographs of Group I (control) fish showing compact hepatocytes $(\mathrm{H})$ and well-spaced sinusoids (S) in liver, normal renal tubules (RT) and glomerulus (G) in kidney. Group II and Group III show vacuolization (V), pyknotic nuclei (PN), inflammation (In) and necrosis (N) in liver. Similarly, kidney show cavity reduction in renal tubule (CRRT), compact glomerulus (CG), necrosis (N) and Hypertrophy (Hy)in a dose dependant manner. (Group I, Control; Group II, 1/20th of 96h-LC50 concentration of Mercuric chloride; Group III 1/10th of 96h-LC50 concentration of Mercuric chloride). 

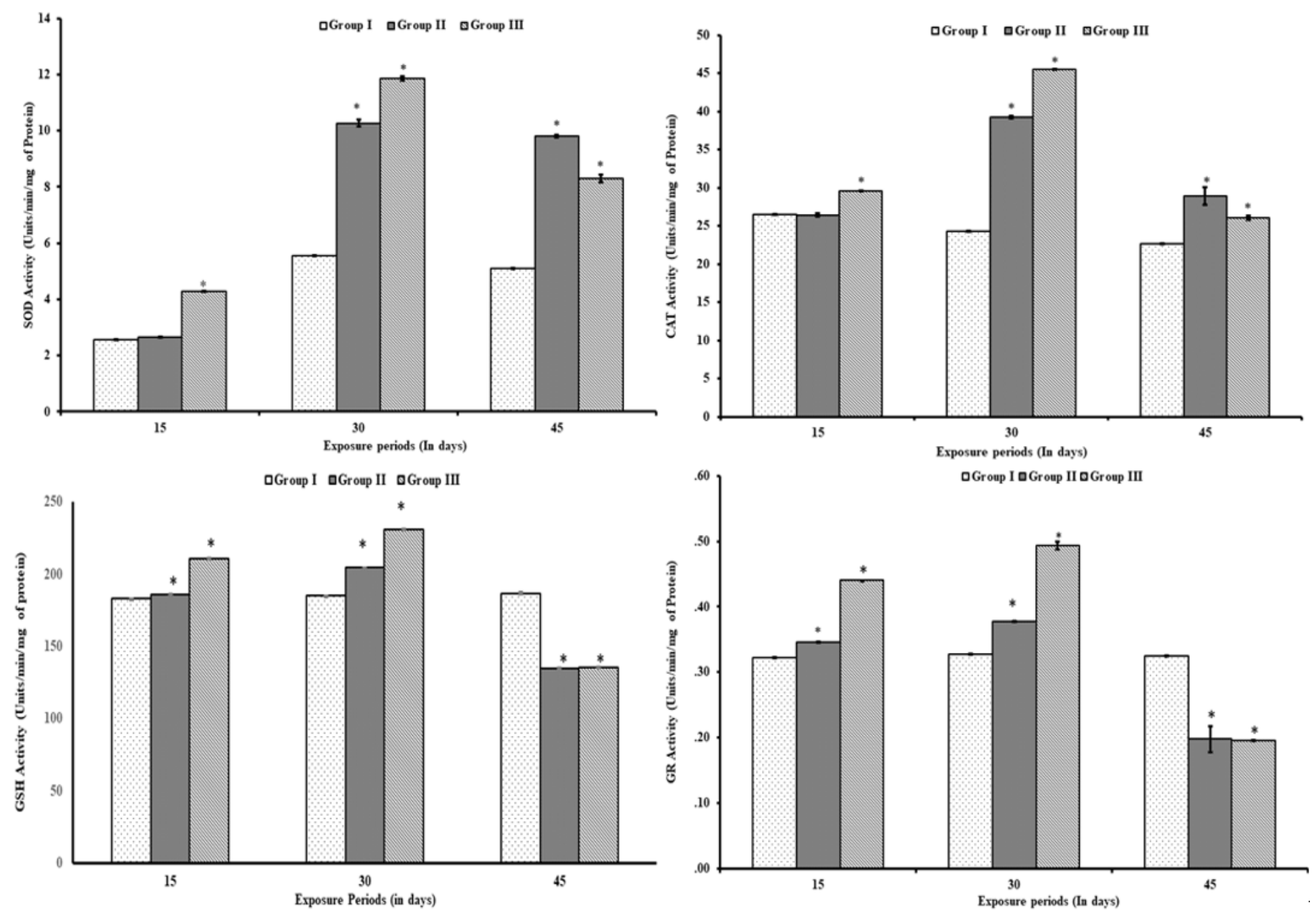

Figure 4

SOD, CAT, GSH and GR activity in control (Group I) and Mercuric chloride treated groups (Group II-1/20th of 96h-LC50 concentration of Mercuric chloride; Group III-1/10th of 96h-LC50 concentration of Mercuric chloride) in liver tissue of fish C. Punctatus for 15, 30 and $45 \mathrm{~d}$ of exposure periods. (Mean $\pm S D, n=3$ fishes of three replicates of each group). (*represent the significant $(p<0.05)$ difference from control). 

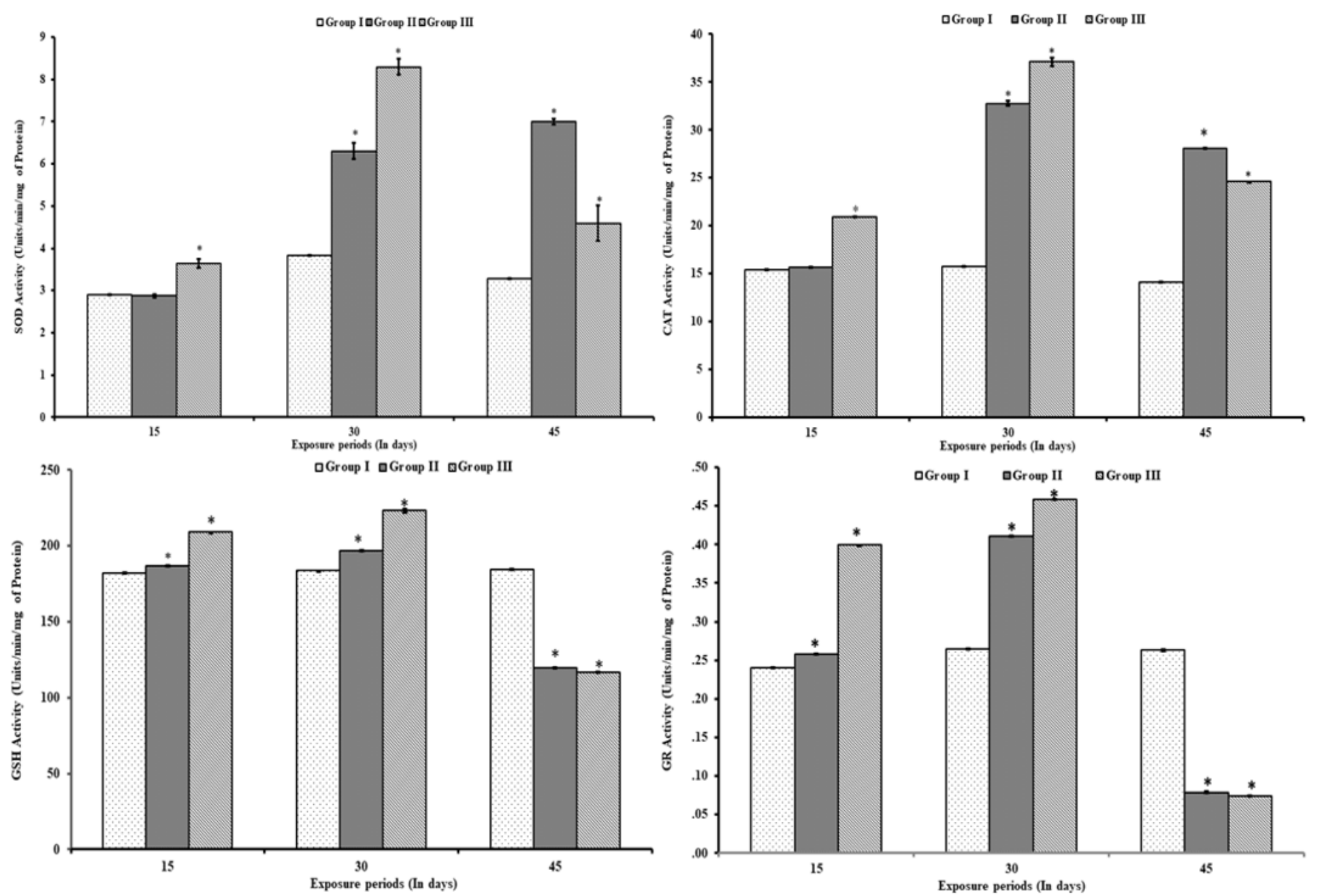

Figure 5

SOD, CAT, GSH and GR activity in control (Group I) and Mercuric chloride treated groups (Group II-1/20th 96h-LC50 concentration of Mercuric chloride; Group III-1/10th 96h-LC50 concentration of Mercuric chloride) in kidney tissue of fish C. punctatus for 15,30 and $45 \mathrm{~d}$ of exposure periods. (Mean $\pm S D, n=3$ fishes of three replicates of each group). (*represent the significant $(p<0.05)$ difference from control). 


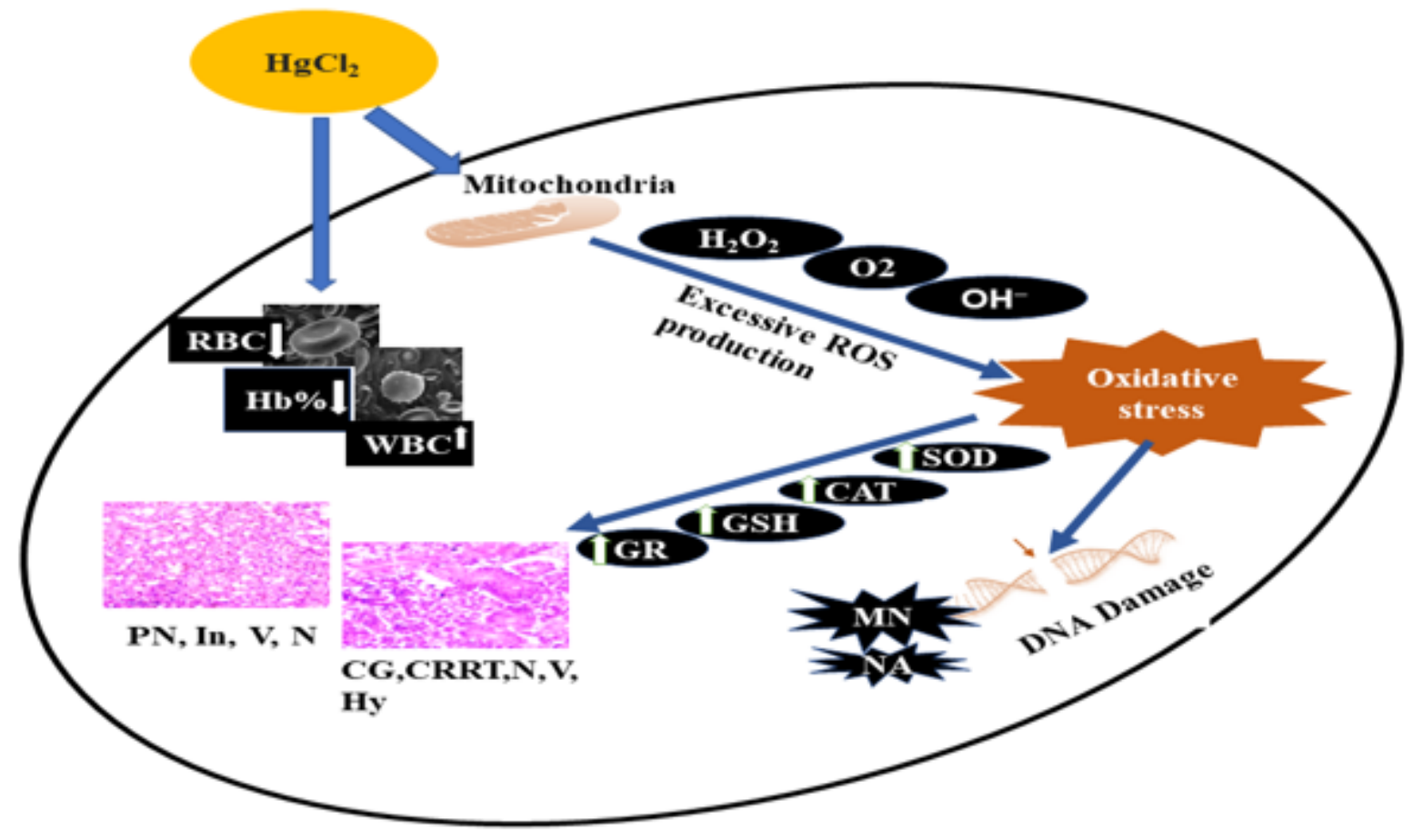

Figure 6

Schematic diagram to depict the plausible mechanism of $\mathrm{HgCl} 2$ induced haematological changes, disbalance in antioxidant system and consequent oxidative stress triggering the induction of micronuclei and nuclear anomalies and histopathological changes in the liver and kidney of fish, C. punctatus. 